Review

\title{
Curative therapy for hemoglobinopathies: an International Society for Cell \& Gene Therapy Stem Cell Engineering Committee review comparing outcomes, accessibility and cost of ex vivo stem cell gene therapy versus allogeneic hematopoietic stem cell transplantation
}

\author{
Alexis Leonard ${ }^{1}$, Alice Bertaina ${ }^{2}$, Carmem Bonfim $^{3}$, Sandra Cohen ${ }^{4}$, Susan Prockop ${ }^{5}$, \\ Duncan Purtill ${ }^{6}$, Athena Russell ${ }^{7}$, Jaap Jan Boelens ${ }^{8,9}$, Robert Wynn ${ }^{10}$, Annalisa Ruggeri ${ }^{11, *}$, \\ Allistair Abraham ${ }^{12, * * * *}$ \\ ${ }^{1}$ Division of Hematology, Children's National Hospital, Washington, DC, USA \\ ${ }^{2}$ Division of Hematology, Oncology, Stem Cell Transplantation and Regenerative Medicine, Department of Pediatrics, Stanford University, Stanford, California, USA \\ ${ }^{3}$ Pediatric Bone Marrow Transplantation Division, Hospital Pequeno Principe, Curitiba, Brazil \\ ${ }^{4}$ Université de Montréal and Maisonneuve Rosemont Hospital, Montréal, Canada \\ ${ }^{5}$ Stem Cell Transplantation and Cellular Therapies, Department of Pediatrics, Memorial Sloan Kettering Cancer Center, New York, New York, USA \\ ${ }^{6}$ Department of Haematology, Fiona Stanley Hospital, Perth, Australia \\ ${ }^{7}$ Center for Cellular Immunotherapies, University of Pennsylvania, Philadelphia, Pennsylvania, USA \\ ${ }^{8}$ Stem Cell Transplantation and Cellular Therapies, Memorial Sloan Kettering Cancer Center, New York, New York, USA \\ ${ }^{9}$ Department of Pediatrics, Weill Cornell Medical College of Cornell University, New York, New York, USA \\ ${ }^{10}$ Faculty of Biology, Medicine and Health, The University of Manchester, Manchester, UK \\ ${ }^{11}$ Department of Hematology and bone marrow transplantation, IRCCS Ospedale San Raffaele, Segrate, Milan, Italy \\ ${ }^{12}$ Center for Cancer and Immunology Research, CETI, Children's National Hospital, Washington, DC, USA
}

\section{A R T I C L E I N F O}

Article History:

Received 10 June 2021

Accepted 4 September 2021

\section{Key Words:}

Gene therapy

hematopoietic cell transplant

sickle cell disease

thalassemia

\begin{abstract}
A B S T R A C T
Thalassemia and sickle cell disease (SCD) are the most common monogenic diseases in the world and represent a growing global health burden. Management is limited by a paucity of disease-modifying therapies; however, allogeneic hematopoietic stem cell transplantation (HSCT) and autologous HSCT after genetic modification offer patients a curative option. Allogeneic HSCT is limited by donor selection, morbidity and mortality from transplant conditioning, graft-versus-host disease and graft rejection, whereas significant concerns regarding long-term safety, efficacy and cost limit the broad applicability of gene therapy. Here the authors review current outcomes in allogeneic and autologous HSCT for transfusion-dependent thalassemia and SCD and provide our perspective on issues surrounding accessibility and costs as barriers to offering curative therapy to patients with hereditary hemoglobinopathies.
\end{abstract}

(c) 2021 International Society for Cell \& Gene Therapy. Published by Elsevier Inc. All rights reserved.

\section{Introduction}

Thalassemia major and sickle cell disease (SCD) are the two most frequent hereditary hemoglobinopathies in the world. The annual birth rate is estimated to increase from the current 300000 to over 400000 births in the next several decades, $80 \%$ of which occur in low- or middle-income countries [1]. Thalassemia major and SCD therefore represent a growing global health burden, and treatment options that aim to reduce the burden of disease are needed.

\footnotetext{
** Correspondence: Allistair Abraham, MD, Center for Cancer and Immunology Research, Cell Enhancement and Technologies for Immunotherapy, Children's National Hospital, 111 Michigan Avenue NW, Washington, DC 20010, USA.

E-mail address: aabraham@childrensnational.org (A. Abraham).

* These authors contributed equally to this work.
}

Despite a significant increase in survival for patients with thalassemia with regular blood transfusions, iron chelation therapy, evidence-based practice guidelines, splenectomy and antibiotic prophylaxis [2,3], complications directly from transfusion therapy or indirectly from iron overload and organ damage increase the medical burden of disease as much as $10-15 \%$ per patient [4-6]. Recently, luspatercept (previously called ACE-536) was approved by the Food and Drug Administration for the treatment of adults $>18$ years of age with transfusion-dependent thalassemia (TDT) as an agent that improves red blood cell (RBC) maturation by an incompletely understood mechanism.

Hydroxyurea (HU) is efficacious in reducing SCD-related complications and is therefore a routine consideration as early as 9 months of age before protective fetal hemoglobin (HbF) levels fall and SCD- 
related complications begin to occur [7-10]. HU must, however, be continued indefinitely with close monitoring, which may contribute to low uptake and adherence. Newer Food and Drug Administrationapproved therapies include L-glutamine and crizanlizumab to reduce pain events and voxelotor to improve anemia; however, the role of these drugs in the management of patients with SCD remains unclear. In addition, the costs of these new drugs provide additional barriers to broad access. Similarly, chronic blood transfusion therapy requires a patient's time and commitment, carries the risk of iron overload and alloimmunization and does not fully eliminate the complications of the disease.

Given the burden of disease and limitations of disease-modifying therapies currently available for SCD and TDT, curative strategies are needed. As RBC disorders, both SCD and TDT can be cured by hematopoietic stem cell transplantation (HSCT); however, the use of HSCT is limited in both conditions by a paucity of available HLA-identical sibling donors and well-matched unrelated donors (MUDs) [11,12]. Although allogeneic HSCT is limited by donor availability, morbidity and mortality from transplant conditioning, graft-versus-host disease (GVHD) and graft rejection, gene therapy, either by gene addition or gene modification, targeting autologous hematopoietic stem cells (HSCs) may become a universal cure for SCD and TDT that eliminates the major limitations of allogeneic transplantation. Here the authors review and provide perspectives on the outcomes, accessibility and cost of ex vivo stem cell gene therapy versus allogeneic HSCT in TDT and SCD.

\section{Indications for and Limitations of Allogeneic HSCT for TDT and SCD in the Current Era}

Transfusion dependence due to thalassemia is the principal indication for HSCT. Challenges of providing blood, chelation therapy, adequate monitoring and patient support, particularly in developing countries, hinder transfusion with chelation as an effective treatment modality [13]. Children with TDT and a suitable, unaffected, HLAidentical sibling should be offered HSCT as early as possible to avoid complications associated with chronic transfusions and iron overload. Outcomes from HSCT correlate with severity of iron overload and duration of exposure; thus, outcomes are best in individuals in whom the risks of organ damage from excess iron stores have been minimized [14].

Clinical phenotypes of SCD are extremely variable, and there is no clear definition of symptomatic SCD; thus, unlike TDT, there are no universal, widely adopted indications for HSCT in SCD. The presence of central nervous system disease is generally acceptable for HSCT given the risk of second overt strokes or progressive cerebral infarcts despite adequate transfusion therapy [15,16]. Recurrent vaso-occlusive crisis (VOC) despite HU, recurrent acute chest syndrome, osteonecrosis, sickle nephropathy, red cell alloimmunization, pulmonary hypertension and recurrent splenic sequestration encompass other "severe" disease complications that may be considered indications for HSCT [17], but most of these reflect expert opinion.

HSCT for either TDT or SCD is limited by disease complications, the preparative regimen and the graft source, all of which contribute to peritransplant morbidity and mortality. Patients with both TDT and SCD exhibit ineffective erythropoiesis; therefore, mixed donor chimerism is sufficient in part because of the competitive advantage of donor RBCs [18-20]. Studies investigating reduced intensity conditioning (RIC) regimens have reported similar overall survival (OS) and event-free survival (EFS) with lower toxicity [21-23] compared with myeloablative regimens. However, standard preparative regimens currently utilize myeloablation to efficiently lower the barrier for engraftment and minimize graft rejection, and therefore some patients are excluded from HSCT based solely on the ability to tolerate myeloablation. Some modifications may be made in high-risk patients [24-28]; however, deviation from myeloablative therapy remains under investigation and is currently done under clinical trials. Furthermore, both TDT and SCD patients exhibit an intact immune system, and hyperinflammation specific to SCD, requiring sufficient immunosuppression for sustained engraftment. In general, patients with stable donor engraftment after HSCT do not experience sickle-related complications after HSCT in SCD, or require ongoing transfusion support in TDT, with stabilization or even improvement in end-organ pathology. However, this is balanced by a significant risk of infertility, which remains a major barrier and important concern for patients and families [22,23,29-32].

\section{Outcomes: Allogeneic HSCT in TDT and SCD}

\section{HLA-matched sibling donor HSCT}

The effectiveness of HSCT for TDT with HLA-matched sibling donor was established in the 1980s [33], with reported OS and disease-free survival (DFS) now approaching $91 \%$ and $83 \%$, respectively, with bone marrow (BM) from HLA-identical siblings [34]. Similarly, proof of concept for cure of SCD after HSCT occurred in 1984 when a child with sickle cell anemia developed acute myelogenous leukemia (AML) and was cured of both her AML and SCD after HLA-matched sibling HSCT [35]. Since then, over 1000 patients with SCD have successfully undergone HSCT with an HLA-identical sibling donor, with greater than $90 \%$ of all patients cured of SCD [36,37]. Table 1 is a partial summary of HLA-identical HSCT in TDT and SCD over the last 5 years.

Initial experiences in matched sibling HSCT in TDT formalized three independent prognostic factors (Pesaro classification): hepatomegaly $>2 \mathrm{~cm}$, portal fibrosis and history of inadequate iron chelation therapy [38]. DFS of $87 \%, 85 \%$ and $80 \%$ for Pesaro class I, II and III recipients, respectively, demonstrated that optimal lifelong transfusion and chelation therapy, preventing anemia and iron-related tissue damage, is critical for transplant success. Subsequently, age $>14$ years was established as an independent risk factor [39], though after adjusting for donor type and conditioning regimen, new data suggest the best outcome is in patients aged $\leq 6$ years [40]. Modifications in conditioning with the addition of Thiotepa (TT) have improved outcomes for patients with Pesaro class III recipients [41].

Similarly, the largest international survey of results of HLA-identical sibling HSCT in SCD identified several key factors associated with survival after transplantation: age, graft type and transplant period [36]. The 5-year EFS and OS of over 1000 patients worldwide were 91.4\% and $92.9 \%$, respectively; there was no difference in EFS or OS based on preparative regimen (myeloablative versus non-myeloablative); EFS decreased with increasing age at transplantation; and EFS improved in patients transplanted after 2006 given improvements in supportive care and prevention and management of complications. The use of non-myeloablative or RIC regimens is more common in SCD than TDT, currently demonstrates an acceptable OS and EFS with very little morbidity or GVHD [22,23,42-46] and is being trialed in patients with TDT [47]. By using reduced toxicity with immunomodulatory conditioning, engraftment is still achieved and allows older adults who have accumulated end-organ damage, those refractory to $\mathrm{HU}$, and those who have developed severe alloimmunization to be eligible for curative therapy.

Compared with BM as the source of HSCs, HLA-matched sibling cord blood (CB) is associated with similar OS and DFS but decreased rates of both acute GVHD (aGVHD) and chronic GVHD (cGVHD) in patients with hemoglobinopathies [48]. Conversely, compared with $\mathrm{BM}$, significantly higher rates of both aGVHD and cGVHD are reported when peripheral blood stem cells (PBSCs) are used in patients with TDT, despite similar 2-year OS and DFS [49]. In SCD, lower OS is demonstrated for PBSC transplanation recipients compared to those receiving $\mathrm{BM}$ as a stem cell source [36]. 
Table 1

Allogeneic Transplant for TDT and SCD

\begin{tabular}{|c|c|c|c|c|c|c|c|}
\hline \multicolumn{8}{|c|}{ Matched Sibling Donors } \\
\hline Author (reference) & Published & Disease & Number & Myeloablation & OS & EFS & aGVHD/cGVHD \\
\hline Saraf (44) & 2016 & SCD & 13 & No & $100 \%$ & $93 \%$ & $0 / 0$ \\
\hline Baronciani (39) & 2016 & TDT & 1061 & NR & $91 \%$ & $83 \%$ & $7 \% / 5 \%$ \\
\hline Gaziev (41) & 2016 & $\mathrm{TDT}^{+}$ & 37 & Yes & $92 \%$ & $92 \%$ & $28 \% / 6 \%$ \\
\hline Gluckman (36) & 2017 & SCD & 1000 & Yes $(\mathrm{n}=873 ; 87 \%)$ & $92.9 \%$ & $91.4 \%$ & $14.8 \% / 14.3 \%$ \\
\hline Eapen (37) & 2019 & SCD & 558 & Yes $(n=348 ; 62 \%)$ & $96.2 \%$ & $90.7 \%$ & $11.6 \% / 18.1 \%$ \\
\hline $\operatorname{Li}(40)$ & 2019 & TDT & 677 & Yes & $89 \%$ & $86 \%$ & $11.8 \% / 8.3 \%$ \\
\hline Guilcher (43) & 2019 & SCD & 16 & No & $100 \%$ & $100 \%$ & $0 / 0$ \\
\hline Krishnamurti (45) & 2019 & SCD & $22^{*}$ & No & $94 \%$ & $94 \%$ & $18 \% / 29 \%$ \\
\hline Bernaudin (117) & 2020 & SCD & $234^{* *}$ & Yes & $97 \%$ & $93.9 \%$ & $20.1 \% / 10.5 \%$ \\
\hline Shin (47) & 2020 & TDT, SCD & $9(\mathrm{TDT}) ; 4(\mathrm{SCD})$ & No & $91.7 \%$ & $91.7 \%$ & $20 \% / 20 \%$ \\
\hline Swaminathan (53) & 2020 & TDT & 177 & Yes & $95 \%$ & $96 \%$ & $41 \% / 17 \%$ \\
\hline Alzahrani (46) & 2021 & SCD & 122 & No & $93 \%$ & $87 \%$ & $1.6 \% / 0$ \\
\hline \multicolumn{8}{|c|}{ Matched Unrelated/Mismatched Cord Blood Donors } \\
\hline Shenoy (57) & 2016 & SCD & 29 & No & $79 \%$ & $69 \%$ & $28 \% / 62 \%$ \\
\hline Abraham (18) & 2017 & SCD & 9 & No & $100 \%$ & $78 \%$ & $33 \% / 33 \%$ \\
\hline $\operatorname{Li}(40)$ & 2019 & TDT & 252 & Yes & $87 \%$ & $82 \%$ & $21.5 \% / 8.4 \%$ \\
\hline Sun $(56)$ & 2019 & TDT & 48 & Yes & $100 \%$ & $100 \%$ & $8.3 \% / 8.3 \%$ \\
\hline Gluckman (59) & 2020 & SCD & 71 & Yes & $88 \%$ & $62 \%$ & $23 \% / 23 \%$ \\
\hline Gluckman (58) & 2020 & SCD & $144^{\wedge}$ & Yes & $86 \%$ & $72 \%$ & $24 \% / 24 \%$ \\
\hline Swaminathan (53) & 2020 & TDT & 58 & Yes & $87 \%$ & $84 \%$ & $60 \% / 20 \%$ \\
\hline Feng (68) & 2021 & TDT & 10 & Yes & $90 \%$ & $80 \%$ & $44 \% / 67 \%$ \\
\hline \multicolumn{8}{|c|}{ Haploidentical Donors } \\
\hline Fitzhugh (73) & 2017 & TDT, SCD & 2(TDT);21(SCD) & No & $87 \%$ & $50 \%$ & $0 / 0$ \\
\hline Gilman (83) & 2017 & $\mathrm{SCD}$ & 8 & No & $88 \%$ & $88 \%$ & $25 \% / 13 \%$ \\
\hline Gaziev (82) & 2018 & TDT, SCD & 11(TDT);3(SCD) & Yes & $84 \%$ & $69 \%$ & $28 \% / 21 \%$ \\
\hline Pawlowska (75) & 2018 & SCD & 4 & Yes & $100 \%$ & $100 \%$ & $0 / 75 \%$ \\
\hline de la Fuente (77) & 2019 & SCD & 15 & No & $100 \%$ & $93 \%$ & $20 \% / 6 \%$ \\
\hline Foell (81) & 2019 & SCD & 20 & No & $90 \%$ & $90 \%$ & $35 \% / 30 \%$ \\
\hline Bolanos-Meade (72) & 2019 & TDT, SCD & 5(TDT);12(SCD) & No & $100 \%$ & $94 \%$ & $24 \% / 18 \%$ \\
\hline Cairo (78) & 2019 & SCD & 19 & Yes & $84 \%$ & $84 \%$ & $6.2 \% / 6.7 \%$ \\
\hline Foell (85) & 2020 & SCD & 25 & Yes & $88 \%$ & $88 \%$ & $28 \% / 16 \%$ \\
\hline Anurathapan (79) & 2020 & TDT & 83 & Yes & $96 \%$ & $96 \%$ & $42 \% / 45 \%$ \\
\hline
\end{tabular}

aGVHD: acute graft-vs-host-disease; cGVHD: chronic graft-vs-host-disease; NR: not reported; SCD: sickle cell disease; TDT: transfusion dependent thalassemia. ${ }^{+}$TDT class 3 recipients treated with a modified preparatory conditioning regimen.

Entire cohort $(\mathrm{n}=22)$ included 17 patients who received marrow from an HLA-identical sibling donor and 5 patients who received marrow from an 8/8 HLA-allele matched unrelated donor.

" French series of 234 patients with SCD who received a matched-sibling-donor stem cell transplantation following standardized myeloablative conditioning between 1988 to 2012 . $^{\wedge}$ Cohort $(n=144)$ includes data on 70 unrelated adult donors (49\%), six unrelated cord blood (4\%), and 68 haploidentical donors

The authors agree with recommendations from the European Society for Blood and Marrow Transplantation working groups suggesting that young TDT patients with an available HLA-identical sibling should be offered HSCT as soon as possible before development of iron overload and iron-related tissue damage [1], transplantrelated risk factors should be evaluated according to the Pesaro risk score [2], CB and BM from HLA-matched sibling donors are equally effective stem cell sources [3] and routine use of PBSC transplantation should be avoided because of the increased risk of cGVHD [4]. With regard to patients with $S C D$, young patients with symptomatic SCD who have an HLA-matched sibling donor should be transplanted as early as possible, preferably at pre-school age, with unmanipulated $\mathrm{BM}$ or $\mathrm{CB}[34]$.

\section{Alternative donor outcomes}

Despite some improvements in alternative donor outcomes, HSCT from a non-HLA-matched sibling donor should be considered an experimental approach and should be conducted in the context of well-designed trials. Table 1 is a partial summary of unrelated donor and haploidentical HSCT in TDT and SCD over the last 5 years.

\section{Unrelated donors}

MUD HSCT in TDT is limited by a high incidence of aGVHD and cGVHD and inferior OS and DFS compared with matched sibling HSCT [50-53]. A higher risk of alloreactive reactions is noted with higher Pesaro risk class and older age, and improved results are reported with high-resolution molecular typing for both HLA class I and II molecules and according to stringent criteria of compatibility with the recipient $[54,55]$. In an attempt to improve outcomes, changes to preparative regimens have been trialed [24,56]. TT and fludarabine were added to the classic preparative busulfan $(\mathrm{Bu}) /$ cyclophosphamide (Cy)-based regimen, reducing the Bu dose by one third to decrease lung and liver toxicity [24]. No statistically significant difference was observed between the matched sibling and MUD groups in terms of 3-year OS, treatment-free survival, treatmentrelated mortality, cumulative incidence of graft failure and grade III-IV aGVHD. Expert recommendations are if a well-MUD is available, allogeneic HSCT is a suitable option for a child with lifelong control of iron overload and absence of iron-related tissue complications. The unrelated donor must be selected using high-resolution molecular typing for both HLA class I and II loci and according to stringent criteria of compatibility with the recipient [34] and BM as stem cell source.

The current experience with MUD HSCT for SCD is limited, with mixed results, and primarily restricted by high rates of GVHD and rejection [57-59]. A reduced-toxicity regimen is now being tested in a comparative trial of HSCT and standard of care based on the availability of a suitable HLA-matched related or unrelated donor (BMT CTN 1503, NCT01565616).

Unrelated umbilical CB HSCT is reported to have high rates of graft failure and delayed hematopoietic recovery secondary to low stem cell content $[60,61]$. In SCD, trials using unrelated CB are limited by 
small numbers and show high rates of graft rejection and infection [48,61-65]. The umbilical CB arm of the sickle cell unrelated donor transplant trial of the Blood and Marrow Transplant Clinical Trials Network (BMT CTN 0601) was suspended because of a high incidence of graft rejection and low DFS [63]. The conditioning regimen has been modified to include HU and TT, with a reported DFS and OS in nine patients of $78 \%$ and $100 \%$, respectively, with $33 \% \operatorname{GVHD}(\mathrm{n}=3)$ at a median follow-up of 2 years [18]. When higher cell doses were used in TDT, the 5-year OS and EFS were $88.3 \%$ and $73.9 \%$, respectively [66]. Strategies to improve outcomes in unrelated CB HSCT include the use of multiple CB units [67,68]; combining CB with Tcell-depleted, HLA-haploidentical CD34+ HSCs [69]; and ex vivo expansion of umbilical CB-derived stem and progenitor cells [70,71].

\section{Haploidentical donors}

The major challenge of HLA-haploidentical HSCT is bidirectional alloreactivity leading to a high incidence of graft rejection and GVHD. T-cell depletion strategies (i.e., in vivo post-transplant Cy [PTCy] or ex vivo CD34+ selection of donor grafts) reduce recipient $\mathrm{T}$ cells that recognize the disparate HLA of the haploidentical donor cells and cause graft rejection while also reducing donor T-cell-mediated GVHD. HLA-haploidentical transplantation with PTCy in patients with SCD and TDT demonstrates high OS, limited toxicity and effective reduction of aGVHD and cGVHD in most studies [72-78]. Increasing total body irradiation to $400 \mathrm{cGy}$ resulted in $100 \%$ OS and 94\% EFS (SCD, $\mathrm{n}=12, \beta$-thalassemia, $\mathrm{n}=5$ ), resolution of all GVHD at last follow-up and independence from transfusion in five patients with TDT [72]. The increase in total body irradiation to $400 \mathrm{cGy}$ and addition of TT to the preparative regimen appear to improve engraftment and are being assessed in an ongoing multi-center trial for SCD (BMT CTN 1507, NCT03263559). In TDT, pre-transplant pharmacologic immunosuppression followed by a reduced-toxicity conditioning regimen resulted in a 3-year OS and EFS of $>96 \%$ each, and $7 \%$ severe GVHD in a cohort of 83 patients [79]. Reports of ex vivo $\alpha \beta$ T-cell receptor/ CD19+-depleted grafts or CD3+-depleted/CD34+-selected grafts are limited by small numbers of patients, investigating various conditioning and GVHD prophylactic regimens and reported generally lower EFS and OS and higher GVHD than the PTCy protocols [80-85]. Infectious complications from delayed immune reconstitution and associated morbidity and mortality remain problematic with this overall strategy. Despite these overall improvements in haploidentical models, patient numbers remain small, and more study data are therefore needed to guide clinical practice.

\section{Outcomes: Gene Therapy in TDT and SCD}

\section{Gene transfer outcomes in TDT}

A broad strategy in genetic modification for thalassemia includes insertion of a functional globin gene that sufficiently corrects the globin chain imbalance that is characteristic of thalassemia. This strategy offers wide applicability, given that there are more than 200 individual thalassemia mutations identified, and can be done using lentiviral (LV) transduction of a normally functioning $\beta$-globin gene into autologous HSCs that are then infused as autologous HSCT after myeloablative conditioning. Clinical trials investigating gene transfer for TDT are listed in Table 2.

NCT01745120 and NCT02151526 reported data on 22 patients with TDT who underwent autologous HSCT after transduction with an anti-sickling variant of $\beta$-globin ( $\beta^{\text {T87Q }}$, LentiGlobin BB305) [86]. At a median follow-up of 26 months (range, 15-42), all but one of the 13 patients who had a non- $\beta 0 / \beta 0$ genotype stopped receiving red cell transfusions, and nine patients with a $\beta 0 / \beta 0$ genotype or two copies of the IVS1-110 mutation had a median annualized transfusion volume reduction of $73 \%$, with discontinuation of RBC transfusions in three $(33 \%)$ patients. Levels of $\mathrm{HbA}^{\mathrm{T} 87 \mathrm{Q}}$ ranged from $3.4 \mathrm{~g} / \mathrm{dL}$ to
$10.0 \mathrm{~g} / \mathrm{dL}$ (total hemoglobin [Hb], 8.2-13.7 g/dL). Treatment-related adverse events were typical of those associated with myeloablative $\mathrm{Bu}$. No clonal dominance related to vector integration was observed. This protocol is now being investigated in two phase 3 studies for patients with TDT (NCT03207009) and patients with TDT who do not have a $\beta 0 / \beta 0$ genotype (NCT02906202). Based on the phase $1 / 2$ results, the European Medicines Agency approved this LV product, which contains approximately 24-400 million autologous CD34+ cells transduced with $\mathrm{HbA}^{\mathrm{T} 8 \mathrm{Q}}$, in 2019 for individuals 12 years and older who have TDT with a non- $\beta 0 / \beta 0$ genotype.

NCT02453477 reported data on nine subjects with TDT after direct intra-bone injection of HSCs transduced with the GLOBE LV vector, which encodes a $\beta$-globin gene with a modified enhancer region [87]. With a median follow-up of 18 months, transfusion requirement was eliminated in three of the four evaluable children and was reduced in three adults. Younger age and persistence of higher vector copy number in the repopulating HSCs were associated with better outcome. Adverse events were chemotherapy-related; there were no vector-related concerns. NCT01639690 is investigating transduction with TNS9.3.55, an LV vector encoding the normal $\beta$-globin gene; however, data have not yet been reported.

\section{Gene transfer outcomes in SCD}

Gene addition strategies in SCD involve the addition of an antisickling $\beta$-globin or $\gamma$-globin cassette that overcomes the impaired erythropoiesis associated with sickle $\mathrm{Hb}$. Clinical trials investigating gene transfer for SCD are listed in Table 2. In general, participants undergo a period of transfusions prior to PBSC mobilization and apheresis with plerixafor followed by myeloablative conditioning and cell infusion. Protocols initially used BM harvest as a source of autologous HSCs; however, recent reports suggest higher CD34+ cells/kg yield after plerixafor mobilization, improved transduction efficiency and improved HSC quality compared with BM from subjects with SCD [88-93].

The largest current experience in gene therapy for SCD is the phase $1 / 2$ study evaluating the safety and efficacy of autologous CD34+ HSCs transduced with $\beta^{\text {T87Q }}$, LentiGlobin BB305 (NCT02140554) [94-97]. This has evolved over three cohorts, and as of March 3, 2020, 40 Group C patients (age, 12-38 years) have initiated cell collection and 25 have been treated with the drug product (DP), with a follow-up period of 2.8-24.8 months [95]. In the 16 evaluable patients with $\geq 6$ months of follow-up, total $\mathrm{Hb}$ has ranged from $9.6 \mathrm{~g} / \mathrm{dL}$ to $16.2 \mathrm{~g} / \mathrm{dL}$, with an $\mathrm{HbA}^{\mathrm{T} 87 \mathrm{Q}}$ contribution of $2.7-9.4 \mathrm{~g} /$ $\mathrm{dL}$ and median $\mathrm{HbS} \leq 60 \%$ of total $\mathrm{Hb}$. There is near pancellular expression of $\mathrm{HbA}^{\mathrm{T} 87 \mathrm{Q}} \geq 6$ months post-treatment, with approximately $90 \%$ of RBCs containing $\beta \mathrm{A}^{\mathrm{T} 87 \mathrm{Q}}$ by 18 months and reduction in sickling propensity comparable to sickle cell trait. At last visit posttreatment, key hemolysis markers were trending toward normalization, and no patients required RBC transfusions. Post-treatment, no acute chest syndrome or serious VOCs were observed, and participants reported clinically meaningful improvements in pain reduction at 12 months post-treatment $(\mathrm{n}=5)$.

On February 16, 2021, NCT02140554 and NCT04293185 were placed on a temporary suspension because of a reported suspected unexpected serious adverse reaction (SUSAR) of AML [98]. A patient from the initial Group A of NCT02140554 developed AML 5 years after gene therapy, and the trial was halted to determine if there was any relationship to the use of the LV vector. Additionally, a second SUSAR of myelodysplastic syndrome in a patient from Group $C$ of NCT02140554 is currently being investigated. Prior to suspension, there was one death in Group A related to Bu conditioning and unrelated to LV therapy [99], and there was one death in Group C (unlikely related to LentiGlobin) $>18$ months post-treatment in a patient with significant baseline SCD-related cardiopulmonary disease. Investigations are ongoing to determine the etiology of the 


\begin{tabular}{|c|c|c|c|c|c|c|c|c|c|}
\hline \multicolumn{10}{|c|}{ Gene Transfer Clinical Trials } \\
\hline $\begin{array}{l}\text { ClinicalTrials.gov } \\
\text { Identifier }\end{array}$ & Start Date & Title & Disease & Status & Phase & Age & $\mathrm{N}$ & Study Objective & Location \\
\hline NCT01639690 & 2012 & $\begin{array}{l}\text { B-Thalassemia Major With Autologous CD34+ } \\
\text { Hematopoietic Progenitor Cells Transduced With } \\
\text { TNS9.3.55 a Lentiviral Vector Encoding the Nor- } \\
\text { mal Human } \beta \text {-Globin Gene }\end{array}$ & TDT & $\begin{array}{l}\text { Active, not } \\
\text { recruiting }\end{array}$ & 1 & $>18$ & 10 & $\begin{array}{l}\text { To investigate safety and efficacy of treat- } \\
\text { ment of beta thalassemia major with } \\
\text { autologous CD34+ HPCs Transduced With } \\
\text { TNS9.3.55 a Lentiviral Vector Encoding the } \\
\text { Normal Human B-Globin Gene }\end{array}$ & New York, USA \\
\hline NCT01745120 & 2013 & $\begin{array}{l}\text { A Study Evaluating the Safety and Efficacy of the } \\
\text { LentiGlobin BB305 Drug Product in } \beta \text {-Thalasse- } \\
\text { mia Major Participants }\end{array}$ & TDT & Completed & $1 / 2$ & $12-35$ & 19 & $\begin{array}{l}\text { To evaluate the safety and efficacy of autolo- } \\
\text { gous HCT using LentiGlobin BB305 Drug } \\
\text { Product [autologous CD34+ hematopoietic } \\
\text { stem cells transduced with LentiGlobin } \\
\text { BB305 lentiviral vector encoding the } \\
\text { human } \beta \text { A-T87Q-globin gene] }\end{array}$ & $\begin{array}{l}\text { USA, multicenter; Sydney, } \\
\text { Australia; Bangkok, } \\
\text { Thailand }\end{array}$ \\
\hline NCT02151526 & 2013 & $\begin{array}{l}\text { A Study Evaluating the Efficacy and Safety of Lenti- } \\
\text { Globin BB305 Drug Product in Beta-Thalassemia } \\
\text { Major and SCD }\end{array}$ & TDT, SCD & Completed & $1 / 2$ & $5-35$ & 7 & $\begin{array}{l}\text { To evaluate safety and efficacy of the admin- } \\
\text { istration of LentiGlobin BB305 Drug Prod- } \\
\text { uct to subjects with either beta- } \\
\text { thalassemia major or severe SCD }\end{array}$ & Paris, France \\
\hline NCT02140554 & 2014 & $\begin{array}{l}\text { A Study Evaluating the Safety and Efficacy of the } \\
\text { LentiGlobin BB305 Drug Product in Severe SCD }\end{array}$ & SCD & Suspended & $1 / 2$ & $12-50$ & 50 & $\begin{array}{l}\text { To evaluate gene therapy by transplantation } \\
\text { of autologous CD34+ stem cells trans- } \\
\text { duced ex vivo with the LentiGlobin BB305 } \\
\text { lentiviral vector in subjects with severe } \\
\text { SCD }\end{array}$ & USA, multicenter \\
\hline NCT02186418 & 2014 & Gene Transfer for Patients With SCD & $\mathrm{SCD}$ & $\begin{array}{l}\text { Active, not } \\
\text { recruiting }\end{array}$ & $1 / 2$ & $18-45$ & 10 & $\begin{array}{l}\text { To determine whether transfer of a fetal } \\
\text { hemoglobin gene using a Gamma Globin } \\
\text { Lentivirus Vector into human blood mak- } \\
\text { ing cells is safe and feasible in patients } \\
\text { with SCD }\end{array}$ & $\begin{array}{l}\text { USA, multicenter and } \\
\text { Jamaica }\end{array}$ \\
\hline NCT02247843 & 2014 & Stem Cell Gene Therapy for SCD & SCD & $\begin{array}{l}\text { Active, not } \\
\text { recruiting }\end{array}$ & $1 / 2$ & $>18$ & 6 & $\begin{array}{l}\text { Assess the safety and initial evidence for effi- } \\
\text { cacy of an autologous transplant of } \beta A S 3- \\
\text { FB vector transduced bone marrow CD34+ } \\
\text { cells for adults with severe SCD }\end{array}$ & USA, California \\
\hline NCT02453477 & 2015 & $\begin{array}{l}\text { Gene Therapy for Transfusion Dependent Beta- } \\
\text { thalassemia (TIGET-BTHAL) }\end{array}$ & TDT & $\begin{array}{l}\text { Active, not } \\
\text { recruiting }\end{array}$ & $1 / 2$ & $3-64$ & 10 & $\begin{array}{l}\text { To evaluate safety and efficacy of autologous } \\
\text { hematopoietic stem cells genetically mod- } \\
\text { ified with GLOBE lentiviral vector encod- } \\
\text { ing for the human beta-globin gene for the } \\
\text { treatment of patients affected by TDT }\end{array}$ & Milano, Italy \\
\hline NCT02906202 & 2016 & $\begin{array}{l}\text { A Study Evaluating the Efficacy and Safety of the } \\
\text { LentiGlobin } \otimes \text { BB305 Drug Product in Subjects } \\
\text { With Transfusion-Dependent } \beta \text {-Thalassemia, } \\
\text { Who do Not Have a } \beta 0 / \beta 0 \text { Genotype }\end{array}$ & TDT & $\begin{array}{l}\text { Active, not } \\
\text { recruiting }\end{array}$ & 3 & $<50$ & 23 & $\begin{array}{l}\text { To evaluate the efficacy and safety of autolo- } \\
\text { gous HCT using LentiGlobin BB305 Drug } \\
\text { Product. }\end{array}$ & $\begin{array}{l}\text { USA, multicenter; Mar- } \\
\text { seille, France; Hannover, } \\
\text { Germany; Rome, Italy; } \\
\text { London, UK }\end{array}$ \\
\hline NCT03207009 & 2017 & $\begin{array}{l}\text { A Study Evaluating the Efficacy and Safety of the } \\
\text { LentiGlobin } \otimes \text { BB305 Drug Product in Subjects } \\
\text { With Transfusion-Dependent } \beta \text {-Thalassemia }\end{array}$ & TDT & $\begin{array}{l}\text { Active, not } \\
\text { recruiting }\end{array}$ & 3 & $<50$ & 18 & $\begin{array}{l}\text { To evaluate the efficacy and safety of autolo- } \\
\text { gous HCT using LentiGlobin BB305 Drug } \\
\text { Product }\end{array}$ & $\begin{array}{l}\text { USA, multicenter; Mar- } \\
\text { seille, France; Germany, } \\
\text { multicenter; Thessalo- } \\
\text { niki, Greece; Rome, Italy; } \\
\text { London, UK }\end{array}$ \\
\hline NCT03282656 & 2018 & Gene Transfer for SCD & SCD & Suspended & 1 & $3-40$ & 7 & $\begin{array}{l}\text { To evaluate feasibility of HSC gene transfer } \\
\text { for SCD using autologous BM derived } \\
\text { CD34+ HSCs transduced with a lentiviral } \\
\text { vector containing a short-hairpin RNA tar- } \\
\text { geting BCL11a }\end{array}$ & USA, Massachusetts \\
\hline
\end{tabular}




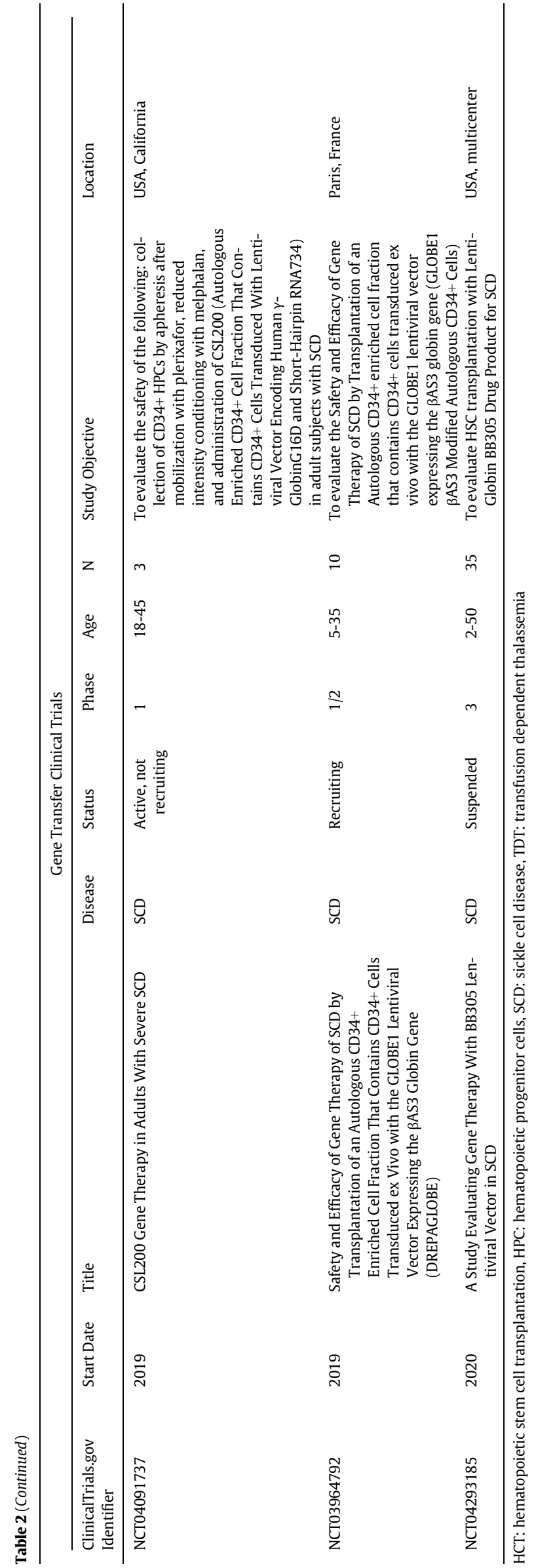

recent SUSAR events, though an updated report suggests that LVderived mutagenesis was unlikely [100,101].

The investigators of NCT03282656 recently published data from six participants (age, 7-25 years) who had follow-up for at least 6 months (range, 7-29) after receiving BCH-BB694 gene therapy (LV vector transfer of a short hairpin RNA targeting BCL11a for increased $\gamma$-globin expression) [102]. HbF induction at most recent follow-up was $20.4-41.3 \%$, with broad distribution of $\mathrm{HbF}$ among red cells. All patients had engraftment, and adverse events were consistent with the effects of preparative chemotherapy. Clinical manifestations of SCD were reduced or absent during the follow-up period. This study has also been paused pending an investigation by the data safety and monitoring board regarding the SUSAR occurrence in the aforementioned, unrelated gene therapy study involving SCD patients.

NCT02186418 is a phase $1 / 2$ study investigating the efficacy and safety of $\gamma$-globin gene transfer, and as of July 28, 2020, data from three patients are available [103]. Participants range in age from 19 years to 34 years, with $6-30$ months of follow-up. Anti-sickling globin expression ranged from $22 \%$ to $38 \%$ at last follow-up, there have been no treatment-related adverse events to date and all participants have maintained improvements in vaso-occlusive events.

\section{Gene editing outcomes in TDT}

Clinical trials investigating gene editing for TDT are listed in Table 3. Given the several hundred mutations in the $\beta$-globin locus that result in TDT, increasing HbF levels rather than directly targeting the $\beta$-globin mutation is a strategy for stabilizing the $\alpha$ : non- $\alpha$ globin ratio sufficiently to prevent intra-marrow apoptosis in developing RBCs.

Results from the first TDT patient treated in NCT03655678, a study investigating CRISPR-Cas9 targeting of the BCL11A erythroidspecific enhancer for increased $\mathrm{HbF}$ expression, were recently reported [104]. Approximately $80 \%$ of the alleles at this locus were modified, with no evidence of off-target editing. More than a year later, there remains high levels of allelic editing in BM and blood and increases in $\mathrm{HbF}$ that were distributed pancellularly and had achieved transfusion independence. Levels of $\mathrm{HbF}$ increased rapidly, from $0.3 \mathrm{~g} / \mathrm{dL}$ at baseline to $13.1 \mathrm{~g} / \mathrm{dL}$ at month 18 , with an increase in Fcell expression, from $10.1 \%$ at baseline to $99.7 \%$ at month 6 , maintained through month 18 . The patient's Hb level normalized to 12.1 $\mathrm{g} / \mathrm{dL}$ at month 4 and remained normal through month 18 .

\section{Gene editing outcomes in SCD}

Clinical trials for gene editing in SCD are focused first on editing $\mathrm{HbF}$ expression rather than directly correcting the sickle mutation, as the former does not require homology-directed repair. Clinical trials investigating gene editing for SCD are listed in Table 3.

Preliminary data in the first two participants in NCT03745287, a study investigating CRISPR-Cas9 editing of the BCL11A erythroid-specific enhancer, were recently published $[104,105]$. Total $\mathrm{Hb}$ and $\mathrm{HbF} \%$ were $10.3 \mathrm{~g} / \mathrm{dL}$ and $42.4 \%$ (12-month follow-up) and $10.0 \mathrm{~g} / \mathrm{dL}$ and $46.8 \%$ (3-month follow-up), respectively. Participants had 7.0 and 7.5 VOCs per year, respectively, prior to enrollment and reported no VOCs after infusion. No other CTX001-related serious adverse events were reported. For one patient with longer follow-up, HbF increased from a baseline of $9.1 \%$ to $43.2 \%$ at month 15 , and F-cell expression was maintained at nearly $100 \%$ through month 15 [104]. This participant had no VOC episodes during the 16.6 months after the infusion of gene-modified cells, and the last transfusion of packed red cells was 19 days after infusion.

One additional study, NCT03653247, is evaluating the safety, tolerability and efficacy of autologous HSCT using BIVV003, a gene editing therapy that uses zinc finger nuclease technology. Information 
Table 3

Clinical Trials in Gene Editing for TDT and SCD

\begin{tabular}{|c|c|c|c|c|c|c|c|c|c|}
\hline \multicolumn{10}{|c|}{ Gene Editing Clinical Trials } \\
\hline $\begin{array}{l}\text { ClinicalTrials.gov } \\
\text { Identifier }\end{array}$ & $\begin{array}{l}\text { Start } \\
\text { Date }\end{array}$ & Title & Disease & Status & Phase & Age & $\mathrm{N}$ & Study Objective & Location \\
\hline $\begin{array}{l}\text { NCT03655678, } \\
\text { NCT03745287 }\end{array}$ & 2018 & $\begin{array}{l}\text { A Safety and Efficacy Study } \\
\text { Evaluating CTX001 in } \\
\text { Subjects With Transfu- } \\
\text { sion-Dependent } \beta \text {-Thal- } \\
\text { assemia (NCT03655678) } \\
\text { or Severe SCD } \\
\text { (NCT03745287) }\end{array}$ & TDT, SCD & Recruiting & $1 / 2$ & $12-35$ & 45 & $\begin{array}{l}\text { To evaluate the safety } \\
\text { and efficacy of autol- } \\
\text { ogous CRISPR-Cas9 } \\
\text { Modified CD34+ } \\
\text { Human HPCs using } \\
\text { CTX001 (autologous } \\
\text { CD34+ HPCs modified } \\
\text { with CRISPR-Cas9 at } \\
\text { the erythroid lineage- } \\
\text { specific enhancer of } \\
\text { the BCL11A gene) }\end{array}$ & $\begin{array}{l}\text { USA, multicenter; } \\
\text { Canada, multicen- } \\
\text { ter; Rome, Italy; } \\
\text { UK, multicenter; } \\
\text { Brussels, Belgium }\end{array}$ \\
\hline NCT03432364 & 2018 & $\begin{array}{l}\text { A Study to Assess the } \\
\text { Safety, Tolerability, and } \\
\text { Efficacy of ST- } 400 \text { for } \\
\text { Treatment of Transfu- } \\
\text { sion-Dependent Beta- } \\
\text { thalassemia (TDT) }\end{array}$ & TDT & $\begin{array}{l}\text { Active, } \\
\text { not } \\
\text { recruiting }\end{array}$ & $1 / 2$ & $18-40$ & 6 & $\begin{array}{l}\text { To understand safety } \\
\text { and tolerability of ST- } \\
400 \text { (zinc finger } \\
\text { nuclease technology } \\
\text { to disrupt a the } \\
\text { BCL11A enhancer), } \\
\text { and secondary objec- } \\
\text { tives are to assess the } \\
\text { effects on fetal hemo- } \\
\text { globin levels and } \\
\text { transfusion } \\
\text { requirements }\end{array}$ & USA, multicenter \\
\hline NCT04211480 & 2019 & $\begin{array}{l}\text { Safety and Efficacy Evalua- } \\
\text { tion of } \gamma \text {-globin Reacti- } \\
\text { vated Autologous } \\
\text { Hematopoietic Stem } \\
\text { Cells }\end{array}$ & TDT & Recruiting & NR & $5-15$ & 12 & $\begin{array}{l}\text { To evaluate the safety } \\
\text { and efficacy of the } \\
\text { treatment with } \gamma \text {-glo- } \\
\text { bin reactivated autol- } \\
\text { ogous hematopoietic } \\
\text { stem cells in subjects } \\
\text { with } \beta \text {-thalassemia } \\
\text { major using Crispr/ } \\
\text { Cas9 gene editing } \\
\text { system }\end{array}$ & Shanghai, China \\
\hline NCT03653247 & 2019 & $\begin{array}{l}\text { A Study to Assess the } \\
\text { Safety, Tolerability, and } \\
\text { Efficacy of BIVV003 for } \\
\text { Autologous HCT in } \\
\text { Patients With Severe SCD } \\
\text { (PRECIZN-1) }\end{array}$ & SCD & Recruiting & $1 / 2$ & $18-40$ & 8 & $\begin{array}{l}\text { To evaluate the safety, } \\
\text { tolerability, and effi- } \\
\text { cacy of autologous } \\
\text { HCT using BIVV003 } \\
\text { (zinc finger nuclease } \\
\text { messenger ribonu- } \\
\text { cleic acid (mRNAs) } \\
\text { targeting the BCL11A } \\
\text { locus }\end{array}$ & USA, multicenter \\
\hline NCT04443907 & 2020 & $\begin{array}{l}\text { Study of Safety and Efficacy } \\
\text { of Genome-edited } \\
\text { Hematopoietic Stem and } \\
\text { Progenitor Cells in SCD }\end{array}$ & SCD & Recruiting & $1 / 2$ & $2-40$ & 30 & $\begin{array}{l}\text { To evaluate two } \\
\text { genome-edited, } \\
\text { autologous, hemato- } \\
\text { poietic stem and pro- } \\
\text { genitor cell (HSPC) } \\
\text { products - OTQ923 } \\
\text { and HIX763 - each } \\
\text { reducing the biologic } \\
\text { activity of BCL11A, } \\
\text { increasing fetal } \\
\text { hemoglobin (HbF) } \\
\text { and reducing compli- } \\
\text { cations of SCD }\end{array}$ & USA, multicenter \\
\hline
\end{tabular}

HCT: hematopoietic stem cell transplantation, HPC: hematopoietic progenitor cells, SCD: sickle cell disease, TDT: transfusion dependent thalassemia

regarding recruitment and/or preliminary results has not yet been published.

\section{Evidence-Based Assessment of Allogeneic HSCT Versus Gene Therapy in TDT and SCD}

Thousands of patients with TDT and SCD have undergone allogeneic HSCT worldwide with high OS [39]. Allogeneic HSCT with either $\mathrm{BM}$ or umbilical $\mathrm{CB}$ is an established therapeutic option for patients with symptomatic SCD and an HLA-matched sibling donor with an OS and EFS of $>90 \%$. Evidence-based assessments for allogeneic HSCT in TDT and SCD are listed in Table 4.
Early gene transfer data demonstrate a possible cure for patients with non- $\beta 0 / \beta 0$ TDT and SCD, and may be considered for patients without a matched sibling donor. The decision to pursue an alternative donor source when there is not an HLA-matched sibling versus autologous gene therapy must take into account multiple factors with regard to outcomes, including transplant efficacy, short- and long-term transplant-associated morbidity and mortality, conditioning regimens, patient disease status, donor/patient match, safety, patient preference, donor availability and cost.

The risks associated with genetic manipulation are significant. LV addition strategies require integration into the host genome; therefore, thousands of insertional mutations occur in a population of treated cells. Likewise, off-target CRISPR-induced DNA modifications 
Table 4

Evidence Based Assessment for Allogeneic HCT and autologous gene therapy in TDT and SCD

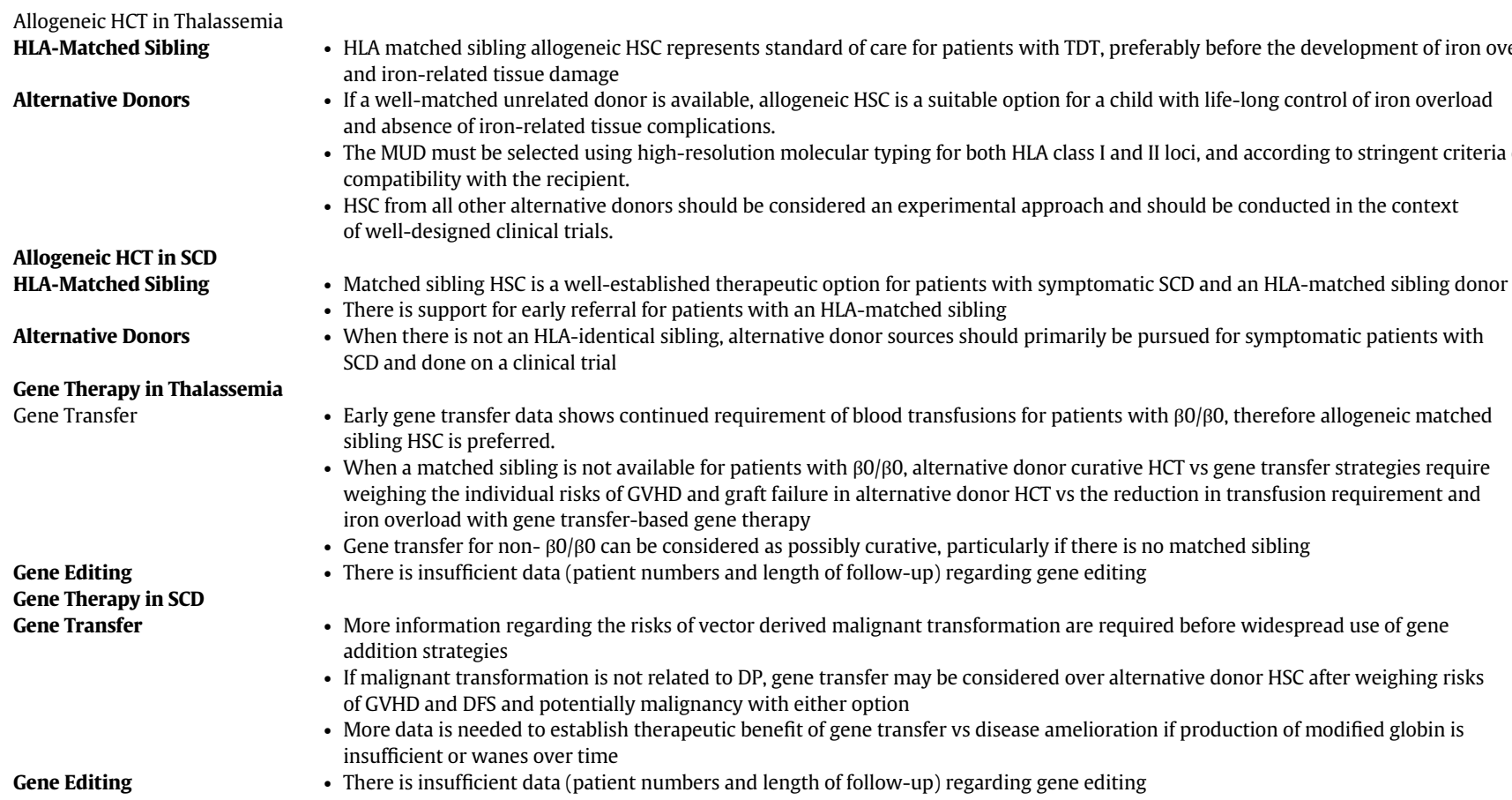

- There is insufficient data (patient numbers and length of follow-up) regarding gene editing

present potentially deleterious off-target effects. Though CRISPR is non-integrating, the requirement for double-stranded DNA breaks may reduce engraftment and proliferative capacity such that a population with proliferative advantages becomes selected for. Though the reports of AML and myelodysplastic syndrome are highly concerning, investigations appear to exonerate vector-mediated dyserythropoiesis [100,101], and multiple factors contribute to the increased risk of post-HSCT malignancy, particularly in patients with SCD [100]. At this time, there are a limited number of patients being treated, and long-term data with regard to gene editing in both TDT and SCD are insufficient to pursue this option without first considering allogeneic HSCT.

\section{Accessibility: Allogeneic HSCT Versus Gene Therapy for Hemoglobinopathies}

The evidence-based assessment regarding accessibility of allogeneic HSCT versus gene therapy in hemoglobinopathies takes into consideration location, follow-up needs and patient eligibility and is summarized in Table 5.

\section{Location}

Both allogeneic HSCT and gene therapy methods require specialized centers for patient care. Both modalities share a common pretransplant period in which the ability to perform HLA screening and collect stem cells is required. During the peritransplant period, both modalities require prolonged hospitalization and adequate resources to support the patient through conditioning, cell infusion and engraftment. Resources necessary during this period include transfusion support, general laboratory services, pharmacy services, ability to screen for blood-borne infections, ability to escalate care in the event of known potential complications and medical expertise, particularly skilled nursing.

Stem cell collection requires a skilled apheresis team and a stem cell processing laboratory. Gene therapy has the added complexity of cell manufacturing, requiring sophisticated labs that are Good Manufacturing Practice-certified. Additionally, all gene therapy applications are conducted in the setting of a clinical trial and therefore have extensive requirements for screening and monitoring that often include multiple specialties and a large investigative team.

The significant infrastructure and health care provider training required to provide curative options for patients with TDT and SCD have prohibited wide adoption where the burden of disease is greatest. The highest prevalence of disease is found in low- and middleincome countries, where easy access to medical care may be limited. Models for HSCT program development exist and include establishing a global partnership, developing infrastructure and building human resource capacity [106]; however, the long-term sustainability of such programs often depends on government resources, which are often limited. Positive patient outcomes and an economic justification for maintenance of HSCT programs are therefore imperative. At the present time, given the breadth of experience and data in the allogeneic setting, exportability may be more suited to allogeneic HSCT than gene therapy.

\section{Follow-up needs}

HSCT conditioning requires myelosuppression to prevent outcompetition by host HSCs and immunosuppression to prevent graft rejection and GVHD. As a result, patients continue to be immunocompromised and require close monitoring and follow-up over a period of months to years. Many variables impact the timing of immune reconstitution, including the conditioning regimen used, source of stem cells and any required manipulation to the graft, degree of HLA match, immunosuppressive therapy, presence of GVHD and use of steroids.

Gene therapy methods have the advantage of not requiring postHSCT immunosuppression for the prevention of GVHD. Gene therapy follow-up is therefore likely less onerous, focusing only on disease resolution and monitoring for malignancy and long-term complications. 
Table 5

Evidence Based Assessment of Accessibility of allogeneic HCT and autologous gene therapy

- Both allogeneic HCT and autologous HCT after genetic modification require specialized centers for stem cell collection and processing, therefore
Location
- Patients require optimized long-term healthcare monitoring of nearly every organ system to ensure post-transplant well-being and early recognition
of late complications.
- Gene therapy follow-up is likely to be less onerous given lack of allogeneic specific complications, therefore gene therapy follow-up may ultimately
be more feasible for developing countries provided the follow-up care is minimal.
- Though the complexity of gene therapy requires a specialized center, the reduced monitoring required post-HCT may allow patients to be
treated in a centralized center but return to their local center for monitoring.
- Both allogeneic HCT and gene therapy require continued monitoring for the development of malignancy post-HCT
- In the current format of using chemotherapy, allogeneic HCT is more feasible for patients with pre-existing co- morbidity as reduced toxicity
conditioning regimens are available
- Myeloablative therapy, and by extension gene therapy in its current form, is limited by the short and long-term toxicities of conditioning
- Gene therapy eligibility is dependent on the ability to collect a sufficient number of CD34+ cells to generate a gene therapy product

Table 6

Evidence Based Assessment of Cost of allogeneic HCT and autologous gene therapy

Cost of allogeneic HCT

Cost of gene therapy vs. allogeneic HCT
- The cost of allogeneic HSC is dependent on donor source, preparative regimen (myeloablative vs. non-myeloablative) and the risk for post-transplant complications

- In the U.S. and Europe gene therapy is more expensive than allogeneic HSC due to increased manufacturing demands

- Gene therapy may ultimately be the more feasible for developing countries provided the follow-up care is minimal. This may allow patients to be treated in a centralized center but return to local center for monitoring

- While upfront costs of either approach may be high, quality-adjusted life-years gained and potential to reduce overal lifetime healthcare costs may render curative therapy cost-effective

- To make curative therapies financially feasible, there is a need to shift from fee-for-service to a value-based payment system
Patients require optimized long-term health care monitoring of nearly every organ system to ensure post-transplant well-being and early recognition of late complications. A consensus summary reviewing late effects after HSCT in children with SCD and thalassemia [107] has now been followed up with comprehensive late effects screening guidelines [108]. Specifically with regard to patients with TDT, the guidelines focus on organ toxicities associated with iron overload and the susceptibility to hepatic veno-occlusive disease. For patients with SCD, monitoring of the central nervous system as well as cardiac, pulmonary and renal systems, in addition to continued management of chronic pain, is critical.

For both TDT and SCD, hypogonadism and risk of infertility are high both pre- and post-HSCT as a result of iron overload, HU use and recurrent priapism in SCD as well as HSCT conditioning regimens. Risks are impacted by the stage of pubertal development at HSCT $[31,109,110]$ and the preparative regimen utilized [111,112]. Presumably, gonadal dormancy and shorter exposure to iron overload contribute to better preservation of fertility when HSCT is performed early in life [113]; however, when not possible, hormonal therapy may be of benefit [112,114-117].

\section{Patient eligibility}

HSCT morbidity is significantly influenced by the preparative conditioning regimen regardless of whether allogeneic or autologous HSCT methodology is used. Therefore, the broad applicability of either curative therapy is limited by the patient's disease status and ability to undergo conditioning.

Unlike current allogeneic HSCT protocols, almost all gene therapy studies utilize myeloablative conditioning to maximize marrow repopulation with genetically modified cells (exception, NCT02186418). In the allogeneic setting, 20-25\% donor myeloid chimerism is sufficient to reverse the sickle phenotype in SCD $[18,19]$, and chimerism as low as $10 \%$ has been reported in TDT [20]; therefore, RIC is possible and may be preferred, though early and late graft failure remains a challenge. RIC allows access to curative therapies for a greater number of patients who may have substantial comorbidities and be otherwise unable to tolerate myeloablation.
There are also additional patient factors that may limit either therapy. A history of antibodies directed against either donor HLA or red cell antigens may preclude a patient from undergoing haploidentical HSCT because of the increased risk of graft rejection and pure red cell aplasia post-HSCT. Desensitization approaches such as plasmapheresis combined with anti-B-cell antibodies (rituximab) and immune modulators (bortezomib) have been used to overcome these concerns in some cases $[118,119]$. With regard to gene therapy, success is dependent on safely obtaining a sufficient quantity of autologous SCD patient HSCs to enable lifelong engraftment. In patients with SCD, steady-state BM harvesting is associated with suboptimal HSC quality and yield [91], and PBSC mobilization with granulocyte colony-stimulating factor is contraindicated [120-122], though single-agent plerixafor mobilization appears to be safe and effective [88-90,93]. Some patients may be unable to mobilize a sufficient number of CD34+ cells following plerixafor administration to generate a gene therapy product. It is likely that these patient factors will be less of a concern in pediatric patients, who have better overall organ function and less exposure to RBC antigens from a lifetime of $\mathrm{RBC}$ transfusions, and this is a compelling reason to offer these therapies earlier in the disease course.

\section{Cost}

The evidence-based assessment regarding the cost of allogeneic HSCT versus gene therapy in hemoglobinopathies takes into consideration the cost of standard of care versus allogeneic HSCT versus gene therapy and is summarized in Table 6.

\section{Cost of standard care for $\mathrm{Hb}$ disorders}

Both TDT and SCD are chronic diseases with high health care utilization; therefore, management becomes more costly over time. Costs for patients with TDT are associated with regular transfusions, iron chelation therapy and monitoring and management of complications, including iron overload and infections [6]. SCD is a chronic, debilitating condition that causes increased organ damage over time. In the US, SCD accounts for an estimated \$1.6 billion per year in health care 
costs [123]. For a patient with TDT who survives to age 50, total health care costs are estimated to be $\$ 720,201$ ( $£ 483,454$ ) [124], and total health care costs are estimated to exceed $\$ 8$ million in a patient with SCD [125]. When addressing health care costs, however, hidden costs are often not factored into health care estimates, including loss of wages due to frequent health care visits, unemployment among patients and parents and reduced quality of life. Although advances in iron chelation in TDT, maximizing HU therapy in SCD and the discovery of new therapeutics improve disease management, a greater focus on curative approaches for these diseases might also represent a suitable strategy for reducing personal lifetime health care costs and improving quality of life.

\section{Cost of allogeneic HSCT in $\mathrm{Hb}$ disorders}

In the US, the majority of HSCT costs (>75\%) for both autologous and allogeneic patients occur during the initial transplant hospitalization and are estimated to be $\$ 100,000$ for autologous HSCT and $\$ 200,000$ for allogeneic HSCT during the first 100 days post-HSCT [126]. Average HSCT cost per patient with TDT is $\$ 251,723$ (€215,571) [127], though significantly lower costs have been approximated in resource-limited countries [53]. Median HSCT cost per patient with SCD is estimated at $\$ 467,747$ (range, $\$ 344,029-799,219$ ) [128], though this may be nearly $50 \%$ lower in patients who receive a non-myeloablative regimen [129]. Such costs therefore limit these therapies to developed countries and countries with higher gross national incomes, governmental health care expenditures and team densities [130]. Nevertheless, resource-limited settings have an increased interest in developing HSCT programs given the potential ability to cure chronic, debilitating and expensive diseases such as TDT and SCD. Although the upfront costs of HSCT are high, chronic diseases exert their deleterious effects over the long term, and interventions that seek to change the course of the disease may be economically justified [129]. Ultimately, the quality-adjusted life-years gained for the patient and the potential to reduce overall lifetime health care costs may render curative therapy cost-effective [131].

\section{Comparison of projected gene therapy costs in the US and Europe versus allogeneic HSCT}

Costs for gene therapy are less certain and suggested to be as high as $\$ 900,000-2.1$ million [132], severely limiting real-world applicability. In the current market, the majority of expenses for gene therapy occur in the pre-transplant period given the complexity of DP collection, manufacture and compliance with safety and regulatory standards in addition to the more intensive preparatory patient management leading up to HSCT. During HSCT, total average medical costs excluding vector costs have been shown to be relatively homogeneous among patients with TDT treated with either allogeneic HSCT (£173,497) or gene therapy $(£ 188,334)[127]$. Patients treated with gene therapy have lower costs in the follow-up period owing to fewer infectious complications, treatments, imaging, outpatient care and inpatient admissions. Gene therapy patients have fewer productivity losses, experience fewer complications and hospital admissions and have a shorter length of hospital stay, but gene therapy costs on average an additional $£ 300,000-400,000$ per patient. Nearly half of this total cost is due to expenses associated with the vector, whereas nearly half of the cost of allogeneic HSCT is due to outpatient care and inpatient admissions. An increase in manufacturer competition and evolution of practices should decrease these manufacturing costs. Increasing the number of patients treated and factoring in age and weight at the time of collection/manufacture could further impact manufacturing costs. Finally, gene editing techniques that utilize more readily available and inexpensive editing tools and eliminate the costly vector component may reduce the overall expenditure and increase the potential broader feasibility of gene therapy.

To justify the additional costs associated with gene therapy, comparing clinical effectiveness with established curative options, assessing value and determining affordability are necessary [133]. Gene therapy trials are non-randomized, single-arm trials using historical cohorts for comparison; therefore, there may be an overestimation of benefit [134]. The assessment of value is similar for allogeneic HSCT versus gene therapy, as curative therapies may be valued more highly by society than treatments that reduce but do not eliminate ongoing costs of patient support and management of chronic comorbidities. Payers typically focus on health gains for the patient and net direct costs to the health system when evaluating payment for therapy, though this does not take into account hidden patient costs. For patients with TDT and SCD, this equates to easily measurable outcomes such as a reduced need for transfusions, hospitalizations, emergency room visits, prescription medications such as treatment for iron overload or acute and chronic pain and health care utilization overall. This does not, however, account for improved quality of life, steady employment, increased wages or other productivity gains. To assess the full financial impact, long-term savings, hidden costs, quality-adjusted life-year adjustments and productivity gains and losses should be included in affordability considerations. Based on the initial pricing experience with gene therapy in Europe, with an estimated upfront treatment price of over US\$1 million per patient, the cumulative budget impact is not sustainable. According to health policy experts, "The cumulative budget impact at that price could rise to US $\$ 3$ trillion, as much as is currently spent in a year on all health care in the USA" [133]. Although there may be a cost benefit to gene editing strategies over vector-based therapies, there are too little data to suggest a clear benefit of one gene therapy methodology over another at this time. Having multiple gene therapy strategies investigated is of utmost benefit to patients who are in search of curative therapies and whose options are limited by donor selection. Data from multiple methodologies maturing simultaneously will help to identify whether there is a superior method, as identified by measurable outcomes, sustainability of therapy (Hb production) over time and safety, all while simultaneously bringing competition into the manufacturing market.

Ultimately, the gene therapy cost model may need to shift from fee-for-service to value-based payment systems [135]. One proposal suggests that $80 \%$ of the cost of gene therapy is put at risk to prove the value of its treatment; after an initial upfront charge, DP manufacturers would get paid only if the one-time infusion continued to benefit patients. Recently, the US Centers for Medicare \& Medicaid Services presented a proposal to ease value-based payment models for gene therapies, increasing payer price negotiating power and the ability to arrange payment based on outcome over quantity [136]. Other proposed mechanisms for handling affordability include reinsurance, consumer loans, third-party financing, manufacturer-managed financing and government financing, though many of these remain untested and impractical [133]. In the current form, the financial burdens of gene therapy preclude the inclusion of this treatment as a realistic option for a cure available to all.

\section{Discussion}

TDT and SCD are growing global health disorders with limited disease-modifying therapies. Both TDT and SCD can be cured by HSCT, with recent evidence suggesting that gene modification of autologous HSCs could become a universal cure. Allogeneic transplantation is limited by donor selection, morbidity and mortality related to transplant conditioning, GVHD and graft rejection, whereas significant concerns regarding long-term safety, efficacy and cost limit the broad applicability of gene therapy. Patient-specific factors and location further limit the widespread applicability of curative therapies. 
Therefore, strategies that aim to improve patient outcomes, reduce disease morbidity and dramatically reduce costs are needed to improve the lives of millions of patients with hereditary hemoglobinopathies.

\section{Declaration of Competing Interest}

JJB is a member of the International Society for Cell \& Gene Therapy Stem Cell Engineering Committee and consults for Avrobio, BlueRock Therapeutics, Race Oncology, Advanced Clinical, Omeros, Sanofi and Medexus Pharmaceuticals. AAA served on the safety monitoring committee for Sangamo Therapeutics. CB consults for Zodiac Pharmaceuticals, Amgen and Novartis. SP receives support for the conduct of clinical trials through Memorial Sloan Kettering from AlloVir, Atara Biotherapeutics and Jasper Therapeutics and is the inventor of intellectual property related to the development of a third-party, virusspecific T-cell program, with all rights assigned to Memorial Sloan Kettering.

\section{Funding}

No funding was received.

\section{Author Contributions}

All authors have approved the final article. All authors contributed to conception/design, acquisition of data, analysis/interpretation, drafting/revising.

\section{References}

[1] Piel FB, Hay SI, Gupta S, Weatherall DJ, Williams TN. Global burden of sickle cell anaemia in children under five, 2010-2050: modelling based on demographics, excess mortality, and interventions. PLoS Med 2013;10(7):e1001484.

[2] Cappellini MD, Cohen A, Porter J, et al., editors. Guidelines for the Management of Transfusion Dependent Thalassaemia (TDT) [Internet]. 3rd edition. Nicosia (CY): Thalassaemia International Federation; 2014. Available from: https://www.ncbi. nlm.nih.gov/books/NBK269382/.

[3] Telfer P. Update on survival in thalassemia major. Hemoglobin 2009;33(Suppl 1):S76-80

[4] Bonifazi F, Conte R, Baiardi P, Bonifazi D, Felisi M, Giordano P, et al. Pattern of complications and burden of disease in patients affected by beta thalassemia major. Curr Med Res Opin 2017;33(8):1525-33.

[5] Borgna-Pignatti C. The life of patients with thalassemia major. Haematologica 2010;95(3):345-8

[6] Borgna-Pignatti C, Cappellini MD, De Stefano P, Del Vecchio GC, Forni GL, Gamberini MR, et al. Survival and complications in thalassemia. Ann N Y Acad Sc 2005; $1054: 40-7$

[7] Steinberg $\mathrm{MH}$, Barton F, Castro O, Pegelow CH, Ballas SK, Kutlar A, et al. Effect of hydroxyurea on mortality and morbidity in adult sickle cell anemia: risks and benefits up to 9 years of treatment. JAMA 2003;289(13):1645-51.

[8] Wang WC, Ware RE, Miller ST, Iyer RV, Casella JF, Minniti CP, et al. Hydroxycarbamide in very young children with sickle-cell anaemia: a multicentre, randomised, controlled trial (BABY HUG). Lancet 2011;377(9778):1663-72.

[9] Ware RE. How I use hydroxyurea to treat young patients with sickle cell anemia. Blood 2010;115(26):5300-11.

[10] Zimmerman SA, Schultz WH, Burgett S, Mortier NA, Ware RE. Hydroxyurea therapy lowers transcranial Doppler flow velocities in children with sickle cell anemia. Blood 2007;110(3):1043-7.

[11] Gragert L, Eapen M, Williams E, Freeman J, Spellman S, Baitty R, et al. HLA match likelihoods for hematopoietic stem-cell grafts in the U.S. registry. N Engl J Med 2014;371(4):339-48

[12] Walters MC, Patience M, Leisenring W, Eckman JR, Buchanan GR, Rogers ZR et al. Barriers to bone marrow transplantation for sickle cell anemia. Biol Blood Marrow Transplant 1996;2(2):100-4

[13] Ladis V, Chouliaras G, Berdoukas V, Chatziliami A, Fragodimitri C, Karabatsos F, et al. Survival in a large cohort of Greek patients with transfusion-dependent beta thalassaemia and mortality ratios compared to the general population. Eur J Haematol 2011;86(4):332-8

[14] Angelucci E, Pilo F, Coates TD. Transplantation in thalassemia: Revisiting the Pesaro risk factors 25 years later. Am J Hematol 2017;92(5):411-3.

[15] Hulbert ML, McKinstry RC, Lacey JL, Moran CJ, Panepinto JA, Thompson AA, et al. Silent cerebral infarcts occur despite regular blood transfusion therapy after first strokes in children with sickle cell disease. Blood 2011;117(3):772-9.
[16] Scothorn DJ, Price C, Schwartz D, Terrill C, Buchanan GR, Shurney W, et al. Risk of recurrent stroke in children with sickle cell disease receiving blood transfusion therapy for at least five years after initial stroke. J Pediatr 2002;140(3):348-54.

[17] Kassim AA, Sharma D. Hematopoietic stem cell transplantation for sickle cell disease: The changing landscape. Hematol Oncol Stem Cell Ther 2017;10(4): 259-66.

[18] Abraham A, Cluster A, Jacobsohn D, Delgado D, Hulbert ML, Kukadiya D, et al. Unrelated Umbilical Cord Blood Transplantation for Sickle Cell Disease Following Reduced-Intensity Conditioning: Results of a Phase I Trial. Biol Blood Marrow Transplant 2017;23(9):1587-92.

[19] Fitzhugh CD, Cordes S, Taylor T, Coles W, Roskom K, Link M, et al. At least 20\% donor myeloid chimerism is necessary to reverse the sickle phenotype after allogeneic HSCT. Blood 2017;130(17):1946-8.

[20] Alfred A, Vora AJ. What is the minimum level of donor chimerism necessary to sustain transfusion independence in thalassaemia? Bone Marrow Transplantation 2011;46(5):769-70.

[21] Anurathapan U, Pakakasama S, Mekjaruskul P, Sirachainan N, Songdej D, Chuansumrit A, et al. Outcomes of thalassemia patients undergoing hematopoietic stem cell transplantation by using a standard myeloablative versus a novel reduced-toxicity conditioning regimen according to a new risk stratification. Biol Blood Marrow Transplant 2014;20(12):2066-71

[22] Hsieh MM, Fitzhugh CD, Weitzel RP, Link ME, Coles WA, Zhao X, et al. Nonmyeloablative HLA-matched sibling allogeneic hematopoietic stem cell transplantation for severe sickle cell phenotype. JAMA 2014:312(1):48-56.

[23] Hsieh MM, Kang EM, Fitzhugh CD, Link MB, Bolan CD, Kurlander R, et al. Allogeneic hematopoietic stem-cell transplantation for sickle cell disease. N Engl J Med 2009;361(24):2309-17.

[24] Li C, Wu X, Feng X, He Y, Liu H, Pei F, et al. A novel conditioning regimen improves outcomes in beta-thalassemia major patients using unrelated donor peripheral blood stem cell transplantation. Blood 2012;120(19):3875-81.

[25] Mathews V, Savani BN. Conditioning regimens in allo-SCT for thalassemia major: Bone Marrow Transplant 2014;49(5):607-10.

[26] Bernardo ME, Zecca M, Piras E, Vacca A, Giorgiani G, Cugno C, et al. Treosulfanbased conditioning regimen for allogeneic haematopoietic stem cell transplantation in patients with thalassaemia major. $\mathrm{Br} J$ Haematol 2008;143(4):548-51.

[27] Bernardo ME, Piras E, Vacca A, Giorgiani G, Zecca M, Bertaina A, et al. Allogeneic hematopoietic stem cell transplantation in thalassemia major: results of a reduced-toxicity conditioning regimen based on the use of treosulfan. Blood 2012;120(2):473-6.

[28] Gaziev J, Marziali M, Isgro A, Sodani P, Paciaroni K, Gallucci C, et al. Bone marrow transplantation for thalassemia from alternative related donors: improved outcomes with a new approach. Blood 2013;122(15):2751-6.

[29] Bernaudin F, Socie G, Kuentz M, Chevret S, Duval M, Bertrand Y, et al. Long-term results of related myeloablative stem-cell transplantation to cure sickle cell disease. Blood 2007:110(7):2749-56.

[30] Dedeken L, Le PQ Azzi N, Brachet C, Heijmans C, Huybrechts S, et al. Haematopoietic stem cell transplantation for severe sickle cell disease in childhood: a single centre experience of 50 patients. Br J Haematol 2014;165(3):402-8.

[31] Walters MC, Hardy K, Edwards S, Adamkiewicz T, Barkovich J, Bernaudin F, et al. Pulmonary, gonadal, and central nervous system status after bone marrow transplantation for sickle cell disease. Biol Blood Marrow Transplant 2010;16 (2):263-72.

[32] Walters MC, Patience M, Leisenring W, Eckman JR, Scott JP, Mentzer WC, et al. Bone marrow transplantation for sickle cell disease. N Engl J Med 1996;335 (6):369-76.

[33] Thomas ED, Buckner CD, Sanders JE, Papayannopoulou T, Borgna-Pignatti C, De Stefano P, et al. Marrow transplantation for thalassaemia. Lancet 1982;2 (8292):227-9

[34] Angelucci E, Matthes-Martin S, Baronciani D, Bernaudin F, Bonanomi S, Cappellini MD, et al. Hematopoietic stem cell transplantation in thalassemia major and sickle cell disease: indications and management recommendations from an international expert panel. Haematologica 2014;99(5):811-20.

[35] Johnson FL, Look AT, Gockerman J, Ruggiero MR, Dalla-Pozza L, Billings 3rd. FT. Bone-marrow transplantation in a patient with sickle-cell anemia. N Engl J Med $1984 ; 311(12): 780-3$

[36] Gluckman E, Cappelli B, Bernaudin F, Labopin M, Volt F, Carreras J, et al. Sickle cell disease: an international survey of results of HLA-identical sibling hematopoietic stem cell transplantation. Blood 2017;129(11):1548-56.

[37] Eapen M, Brazauskas R, Walters MC, Bernaudin F, Bo-Subait K, Fitzhugh CD, et al. Effect of donor type and conditioning regimen intensity on allogeneic transplantation outcomes in patients with sickle cell disease: a retrospective multicentre, cohort study. Lancet Haematol 2019;6(11):e585-96.

[38] Lucarelli G, Galimberti M, Polchi P, Angelucci E, Baronciani D, Giardini C, et al. Bone marrow transplantation in patients with thalassemia. N Engl J Med 1990;322(7):417-21.

[39] Baronciani D, Angelucci E, Potschger U, Gaziev J, Yesilipek A, Zecca M, et al. Hemopoietic stem cell transplantation in thalassemia: a report from the European Society for Blood and Bone Marrow Transplantation Hemoglobinopathy Registry, 2000-2010. Bone Marrow Transplant 2016;51(4):536-41.

[40] Li C, Mathews V, Kim S, George B, Hebert K, Jiang H, et al. Related and unrelated donor transplantation for $\beta$-thalassemia major: results of an international survey. Blood Advances 2019;3(17):2562-70

[41] Gaziev J, Isgro A, Sodani P. Marziali M, Paciaroni K, Gallucci C, et al. Optimal Outcomes in Young Class 3 Patients With Thalassemia Undergoing HLA-Identical Sibling Bone Marrow Transplantation. Transplantation 2016;100(4):925-32. 
[42] Aydogdu S, Toret E, Aksoy BA, Aydin MF, Cipe FE, Bozkurt C, et al. Comparison of Hematopoietic Stem Cell Transplantation Results in Patients with $\beta$-Thalassemia Major from Three Different Graft Types. Hemoglobin 2021;45(1):25-9.

[43] Guilcher GMT, Monagel DA, Nettel-Aguirre A, Truong TH, Desai SJ, Bruce A, et al. Nonmyeloablative Matched Sibling Donor Hematopoietic Cell Transplantation in Children and Adolescents with Sickle Cell Disease. Biol Blood Marrow Transplant 2019;25(6):1179-86.

[44] Saraf SL, Oh AL, Patel PR, Jalundhwala Y, Sweiss K, Koshy M, et al. Nonmyeloablative Stem Cell Transplantation with Alemtuzumab/Low-Dose Irradiation to Cure and Improve the Quality of Life of Adults with Sickle Cell Disease. Biol Blood Marrow Transplant 2016;22(3):441-8.

[45] Krishnamurti L, Neuberg DS, Sullivan KM, Kamani NR, Abraham A, Campigotto F, et al. Bone marrow transplantation for adolescents and young adults with sickle cell disease: Results of a prospective multicenter pilot study. Am J Hematol 2019;94(4):446-54.

[46] Alzahrani M, Damlaj M, Jeffries N, Alahmari B, Singh A, Rondelli D, et al. Nonmyeloablative human leukocyte antigen-matched related donor transplantation in sickle cell disease: outcomes from three independent centres. Br J Haematol 2021;192(4):761-8.

[47] Shin SH, Park SS, Park S, Jeon YW, Yoon JH, Yahng SA, et al. Non-myeloablative matched sibling stem cell transplantation with the optional reinforced stem cell infusion for patients with hemoglobinopathies. Eur J Haematol 2020;105 (4):387-98.

[48] Locatelli F, Kabbara N, Ruggeri A, Ghavamzadeh A, Roberts I, Li CK, et al. Outcome of patients with hemoglobinopathies given either cord blood or bone marrow transplantation from an HLA-identical sibling. Blood 2013;122(6):1072-8.

[49] Ghavamzadeh A, Iravani M, Ashouri A, Mousavi SA, Mahdavi N, Shamshiri A et al. Peripheral blood versus bone marrow as a source of hematopoietic stem cells for allogeneic transplantation in children with class I and II beta thalassemia major. Biol Blood Marrow Transplant 2008;14(3):301-8.

[50] La Nasa G, Giardini C, Argiolu F, Locatelli F, Arras M, De Stefano P, et al. Unrelated donor bone marrow transplantation for thalassemia: the effect of extended haplotypes. Blood 2002;99(12):4350-6.

[51] La Nasa G, Caocci G, Argiolu F, Giardini C, Locatelli F, Vacca A, et al. Unrelated donor stem cell transplantation in adult patients with thalassemia. Bone Marrow Transplant 2005;36(11):971-5

[52] Hongeng S, Pakakasama S, Chuansumrit A, Sirachainan N, Kitpoka P, Udomsubpayakul U, et al. Outcomes of transplantation with related- and unrelated-donor stem cells in children with severe thalassemia. Biol Blood Marrow Transplant 2006;12(6):683-7.

[53] Swaminathan VV, Uppuluri R, Patel S, Ravichandran N, Ramanan KM, Vaidhyanathan L, et al. Matched Family versus Alternative Donor Hematopoietic Stem Cell Transplantation for Patients with Thalassemia Major: Experience from a Tertiary Referral Center in South India. Biol Blood Marrow Transplant. 2020;26 (7):1326-31.

[54] Flomenberg N, Baxter-Lowe LA, Confer D, Fernandez-Vina M, Filipovich A, Horowitz M, et al. Impact of HLA class I and class II high-resolution matching on outcomes of unrelated donor bone marrow transplantation: HLA-C mismatching is associated with a strong adverse effect on transplantation outcome. Blood 2004;104(7):1923-30.

[55] Fleischhauer K, Locatelli F, Zecca M, Orofino MG, Giardini C, De Stefano P, et al. Graft rejection after unrelated donor hematopoietic stem cell transplantation for thalassemia is associated with nonpermissive HLA-DPB1 disparity in hostversus-graft direction. Blood 2006;107(7):2984-92.

[56] Sun L, Wang N, Chen Y, Tang L, Xing C, Lu N, et al. Unrelated Donor Peripheral Blood Stem Cell Transplantation for Patients with beta-Thalassemia Major Based on a Novel Conditioning Regimen. Biol Blood Marrow Transplant 2019;25 (8):1592-6.

[57] Shenoy S, Eapen M, Panepinto JA, Logan BR, Wu J, Abraham A, et al. A trial of unrelated donor marrow transplantation for children with severe sickle cell disease. Blood 2016;128(21):2561-7

[58] Gluckman E, Cappelli B, Scigliuolo GM, De la Fuente J, Corbacioglu S. Alternative donor hematopoietic stem cell transplantation for sickle cell disease in Europe. Hematol Oncol Stem Cell Ther 2020;13(4):181-8.

[59] Gluckman E, Fuente J, Cappelli B, Scigliuolo GM, Volt F, Tozatto-Maio K, et al. The role of HLA matching in unrelated donor hematopoietic stem cell transplantation for sickle cell disease in Europe. Bone Marrow Transplant 2020;55 (10):1946-54.

[60] Strocchio L, Romano M, Cefalo MG, Vinti L, Gaspari S, Locatelli F. Cord blood transplantation in children with hemoglobinopathies. Expert Opinion on Orphan Drugs 2015;3(10):1125-36.

[61] Ruggeri A, Eapen M, Scaravadou A, Cairo MS, Bhatia M, Kurtzberg J, et al. Umbilical cord blood transplantation for children with thalassemia and sickle cell disease. Biol Blood Marrow Transplant 2011;17(9):1375-82.

[62] Adamkiewicz TV, Szabolcs P, Haight A, Baker KS, Staba S, Kedar A, et al. Unrelated cord blood transplantation in children with sickle cell disease: review of four-center experience. Pediatr Transplant 2007;11(6):641-4.

[63] Kamani NR, Walters MC, Carter S, Aquino V, Brochstein JA, Chaudhury S, et al. Unrelated donor cord blood transplantation for children with severe sickle cell disease: results of one cohort from the phase II study from the Blood and Marrow Transplant Clinical Trials Network (BMT CTN). Biol Blood Marrow Transplant 2012;18(8):1265-72.

[64] Locatelli F, Rocha V, Reed W, Bernaudin F, Ertem M, Grafakos S, et al. Related umbilical cord blood transplantation in patients with thalassemia and sickle cell disease. Blood 2003;101(6):2137-43.
[65] Radhakrishnan K, Bhatia M, Geyer MB, Del Toro G, Jin Z, Baker C, et al. Busulfan, fludarabine, and alemtuzumab conditioning and unrelated cord blood transplantation in children with sickle cell disease. Biol Blood Marrow Transplant 2013;19(4):676-7.

[66] Jaing TH, Hung IJ, Yang CP, Chen SH, Chung HT, Tsay PK, et al. Unrelated cord blood transplantation for thalassaemia: a single-institution experience of 35 patients. Bone Marrow Transplant 2012;47(1):33-9.

[67] Sideri A, Neokleous N, Brunet De La Grange P, Guerton B, Le Bousse Kerdilles MC Uzan $G$, et al. An overview of the progress on double umbilical cord blood transplantation. Haematologica 2011;96(8):1213-20.

[68] Feng J, Lee V, Leung AWK, Lam GKS, Chow TTW, Cheng FWT, et al. Double-unit unrelated cord blood transplantation for thalassemia major: Comparison with HLA-identical sibling bone marrow transplantation. Pediatr Transplant 2021;25 (3):e13901.

[69] Kwon M, Bautista G, Balsalobre P, Sanchez-Ortega I, Serrano D, Anguita J, et al. Haplo-cord transplantation using CD34+ cells from a third-party donor to speed engraftment in high-risk patients with hematologic disorders. Biol Blood Marrow Transplant 2014;20(12):2015-22.

[70] Delaney C, Heimfeld S, Brashem-Stein C, Voorhies H, Manger RL, Bernstein ID. Notch-mediated expansion of human cord blood progenitor cells capable of rapid myeloid reconstitution. Nat Med 2010;16(2):232-6.

[71] Horwitz ME, Chao NJ, Rizzieri DA, Long GD, Sullivan KM, Gasparetto C, et al. Umbilical cord blood expansion with nicotinamide provides long-term multilineage engraftment. J Clin Invest 2014;124(7):3121-8.

[72] Bolanos-Meade J, Cooke KR, Gamper CJ, Ali SA, Ambinder RF, Borrello IM, et al. Effect of increased dose of total body irradiation on graft failure associated with HLA-haploidentical transplantation in patients with severe haemoglobinopathies: a prospective clinical trial. Lancet Haematol 2019;6(4):e183-93.

[73] Fitzhugh CD, Hsieh MM, Taylor T, Coles W, Roskom K, Wilson D, et al. Cyclophosphamide improves engraftment in patients with $S C D$ and severe organ damage who undergo haploidentical PBSCT. Blood Adv 2017;1(11):652-61.

[74] Frangoul H, Evans M, Isbell J, Bruce K, Domm J. Haploidentical hematopoietic stem cell transplant for patients with sickle cell disease using thiotepa, fludarabine, thymoglobulin, low dose cyclophosphamide, 200 cGy tbi and post transplant cyclophosphamide. Bone Marrow Transplant 2018;53(5):647-50.

[75] Pawlowska AB, Cheng JC, Karras NA, Sun W, Wang LD, Bell AD, et al. HLA Haploidentical Stem Cell Transplant with Pretransplant Immunosuppression for Patients with Sickle Cell Disease. Biol Blood Marrow Transplant 2018;24 (1):185-9.

[76] Wiebking V, Hutker S, Schmid I, Immler S, Feuchtinger T, Albert MH. Reduced toxicity, myeloablative HLA-haploidentical hematopoietic stem cell transplantation with post-transplantation cyclophosphamide for sickle cell disease. Ann Hematol 2017;96(8):1373-7.

[77] de la Fuente J, Dhedin N, Koyama T, Bernaudin F, Kuentz M, Karnik L, et al. Haploidentical Bone Marrow Transplantation with Post-Transplantation Cyclophosphamide Plus Thiotepa Improves Donor Engraftment in Patients with Sickle Cel Anemia: Results of an International Learning Collaborative. Biol Blood Marrow Transplant 2019:25(6):1197-209.

[78] Cairo MS, Talano JA, Moore TB, Shi Q, Weinberg RS, Grossman B, et al. Familia Haploidentical Stem Cell Transplant in Children and Adolescents With HighRisk Sickle Cell Disease: A Phase 2 Clinical Trial. JAMA Pediatr 2020;174(2): 195-7.

[79] Anurathapan U, Hongeng S, Pakakasama S, Songdej D, Sirachainan N, Pongphitcha P, et al. Hematopoietic Stem Cell Transplantation for Severe Thalassemia Patients from Haploidentical Donors Using a Novel Conditioning Regimen. Biol Blood Marrow Transplant 2020;26(6):1106-12.

[80] Dallas MH, Triplett B, Shook DR, Hartford C, Srinivasan A, Laver J, et al. Longterm outcome and evaluation of organ function in pediatric patients undergoing haploidentical and matched related hematopoietic cell transplantation for sickle cell disease. Biol Blood Marrow Transplant 2013;19(5):820-30.

[81] Foell J, Schulte JH, Pfirstinger B, Troeger A, Wolff D, Edinger M, et al. Haploidentical CD3 or $\alpha / \beta$ T-cell depleted HSCT in advanced stage sickle cell disease. Bone Marrow Transplant 2019;54(11):1859-67.

[82] Gaziev J, Isgro A, Sodani P, Paciaroni K, De Angelis G, Marziali M, et al. Haploidentical HSCT for hemoglobinopathies: improved outcomes with TCRalphabeta (+)/CD19(+)-depleted grafts. Blood Adv 2018;2(3):263-70.

[83] Gilman AL, Eckrich MJ, Epstein S, Barnhart C, Cannon M, Fukes T, et al. Alternative donor hematopoietic stem cell transplantation for sickle cell disease. Blood Adv 2017:1(16):1215-23.

[84] Marzollo A, Calore E, Tumino M, Pillon M, Gazzola MV, Destro R, et al. Treosulfan-Based Conditioning Regimen in Sibling and Alternative Donor Hematopoietic Stem Cell Transplantation for Children with Sickle Cell Disease. Mediterr J Hematol Infect Dis 2017;9(1):e2017014.

[85] Foell J, Kleinschmidt K, Jakob M, Troeger A, Corbacioglu S. Alternative donor: alphass/CD19 T-cell-depleted haploidentical hematopoietic stem cell transplantation for sickle cell disease. Hematol Oncol Stem Cell Ther 2020;13(2):98-105.

[86] Thompson AA, Walters MC, Kwiatkowski J, Rasko JEJ, Ribeil JA, Hongeng S, et al. Gene Therapy in Patients with Transfusion-Dependent beta-Thalassemia. N Engl J Med 2018;378(16):1479-93.

[87] Marktel S, Scaramuzza S, Cicalese MP, Giglio F, Galimberti S, Lidonnici MR, et al Intrabone hematopoietic stem cell gene therapy for adult and pediatric patients affected by transfusion-dependent ss-thalassemia. Nat Med 2019;25(2):234-41.

[88] Boulad F, Shore T, van Besien K, Minniti C, Barbu-Stevanovic M, Fedus SW, et al Safety and efficacy of plerixafor dose escalation for the mobilization of CD34(+) hematopoietic progenitor cells in patients with sickle cell disease: interim results. Haematologica 2018;103(5):770-7. 
[89] Esrick EB, Manis JP, Daley H, Baricordi C, Trebeden-Negre H, Pierciey FJ, et al Successful hematopoietic stem cell mobilization and apheresis collection using plerixafor alone in sickle cell patients. Blood Adv 2018;2(19):2505-12.

[90] Lagresle-Peyrou C, Lefrere F, Magrin E, Ribeil JA, Romano O, Weber L, et al. Plerixafor enables safe, rapid, efficient mobilization of hematopoietic stem cells in sickle cell disease patients after exchange transfusion. Haematologica 2018;103 (5):778-86.

[91] Leonard A, Bonifacino A, Dominical VM, Luo M, Haro-Mora JJ, Demirci S, et al Bone marrow characterization in sickle cell disease: inflammation and stress erythropoiesis lead to suboptimal CD34 recovery. Br J Haematol 2019;186 (2):286-99.

[92] Tisdale JF, Pierciey FJ, Kamble R, Kanter J, Krishnamurti L, Kwiatkowski JL, et al. Successful Plerixafor-Mediated Mobilization, Apheresis, and Lentiviral Vector Transduction of Hematopoietic Stem Cells in Patients with Severe Sickle Cell Disease. Blood 2017;130(Suppl 1):990

[93] Uchida N, Leonard A, Stroncek D, Panch SR, West K, Molloy E, et al. Safe and efficient peripheral blood stem cell collection in patients with sickle cell disease using plerixafor. Haematologica 2020;105(10):e497.

[94] Kanter J, Tisdale JF, Mapara MY, Kwiatkowski JL, Krishnamurti L, Schmidt M, et al. Resolution of Sickle Cell Disease Manifestations in Patients Treated with Lentiglobin Gene Therapy: Updated Results from the Phase 1/2 Hgb-206 Group C Study. Blood 2019;134(Supplement_1):990.

[95] Thompson AA, Walters MC, Mapara MY, Kwiatkowski JL, Krishnamurti L, Aygun $B$, et al. Resolution of Serious Vaso-Occlusive Pain Crises and Reduction in Patient-Reported Pain Intensity: Results from the Ongoing Phase 1/2 HGB-206 Group C Study of LentiGlobin for Sickle Cell Disease (bb1111) Gene Therapy. Blood 2020;136(Supplement 1):16-7.

[96] Kanter J, Walters MC, Hsieh M, Krishnamurti L, Kwiatkowski JL, Kamble R, et al Interim Results from a Phase 1/2 Clinical Study of Lentiglobin Gene Therapy for Severe Sickle Cell Disease. Blood 2017; 130(Suppl 1):527.

[97] Tisdale JF, Kanter J, Mapara MY, Kwiatkowski JL, Krishnamurti L, Schmidt M, et al. Current Results of Lentiglobin Gene Therapy in Patients with Severe Sickle Cell Disease Treated Under a Refined Protocol in the Phase $1 \mathrm{Hgb}-206$ Study Blood 2018;132(Suppl 1):1026.

[98] bluebird bio Announces Temporary Suspension on Phase 1/2 and Phase 3 Studies of LentiGlobin Gene Therapy for Sickle Cell Disease (bb1111) [press release] Business Wire 2021. Feb. 16, 2021

[99] Hsieh MM, Bonner M, Pierciey FJ, Uchida N, Rottman J, Demopoulos L, et al. Myelodysplastic syndrome unrelated to lentiviral vector in a patient treated with gene therapy for sickle cell disease. Blood Adv 2020;4(9):2058-63.

[100] Leonard A, Tisdale JF. A pause in gene therapy: Reflecting on the unique challenges of sickle cell disease. Mol Ther 2021;29(4):1355-6.

[101] bluebird bio Provides Updated Findings from Reported Case of Acute Myeloid Leukemia (AML) in LentiGlobin for Sickle Cell Disease (SCD) Gene Therapy Program [press release]. Business Wire 2021. March 11, 2021

[102] Esrick EB, Lehmann LE, Biffi A, Achebe M, Brendel C, Ciuculescu MF, et al. PostTranscriptional Genetic Silencing of BCL11A to Treat Sickle Cell Disease. N Engl Med 2021;384(3):205-15.

[103] Grimley M, Asnani M, Shrestha A, Felker S, Lutzko C, Arumugam PI, et al. Early Results from a Phase 1/2 Study of Aru-1801 Gene Therapy for Sickle Cell Disease (SCD): Manufacturing Process Enhancements Improve Efficacy of a Modified Gamma Globin Lentivirus Vector and Reduced Intensity Conditioning Transplant. Blood 2020;136(Supplement 1):20-1

[104] Frangoul H, Altshuler D, Cappellini MD, Chen YS, Domm J, Eustace BK, et al. CRISPR-Cas9 Gene Editing for Sickle Cell Disease and beta-Thalassemia. N Engl Med 2021;384(3):252-60.

[105] Frangoul H, Bobruff Y, Cappellini MD, Corbacioglu S, Fernandez CM, de la Fuente J, et al. Safety and Efficacy of CTX001 in Patients with Transfusion-Dependen $\beta$-Thalassemia and Sickle Cell Disease: Early Results from the Climb THAL-111 and Climb SCD-121 Studies of Autologous CRISPR-CAS9-Modified CD34+ Hematopoietic Stem and Progenitor Cells. Blood 2020;136(Supplement 1):3-4.

[106] Yeh AC, Khan MA, Harlow J, Biswas AR, Akter M, Ferdous J, et al. Hematopoietic Stem-Cell Transplantation in the Resource-Limited Setting: Establishing the First Bone Marrow Transplantation Unit in Bangladesh. J Glob Oncol 2018;4:1-10.

[107] Shenoy S, Angelucci E, Arnold SD, Baker KS, Bhatia M, Bresters D, et al. Current Results and Future Research Priorities in Late Effects after Hematopoietic Stem Cell Transplantation for Children with Sickle Cell Disease and Thalassemia: A Consensus Statement from the Second Pediatric Blood and Marrow Transplant Consortium International Conference on Late Effects after Pediatric Hematopoietic Stem Cell Transplantation. Biol Blood Marrow Transplant 2017;23(4): 552-61.

[108] Shenoy S, Gaziev J, Angelucci E, King A, Bhatia M, Smith A, et al. Late Effects Screening Guidelines after Hematopoietic Cell Transplantation (HCT) for Hemoglobinopathy: Consensus Statement from the Second Pediatric Blood and Marrow Transplant Consortium International Conference on Late Effects after Pediatric HCT. Biol Blood Marrow Transplant 2018;24(7):1313-21.

[109] Borgmann-Staudt A, Rendtorff R, Reinmuth S, Hohmann C, Keil T, Schuster FR, et al. Fertility after allogeneic haematopoietic stem cell transplantation in childhood and adolescence. Bone Marrow Transplant 2012;47(2):271-6.

[110] Smith-Whitley K. Reproductive issues in sickle cell disease. Hematology Am Soc Hematol Educ Program 2014;2014(1):418-24.

[111] King AA, Kamani N, Bunin N, Sahdev I, Brochstein J, Hayashi RJ, et al. Successful matched sibling donor marrow transplantation following reduced intensity conditioning in children with hemoglobinopathies. Am J Hematol 2015;90 (12):1093-8

[112] Madden LM, Hayashi RJ, Chan KW, Pulsipher MA, Douglas D, Hale GA, et al Long-Term Follow-Up after Reduced-Intensity Conditioning and Stem Cell Transplantation for Childhood Nonmalignant Disorders. Biol Blood Marrow Transplant 2016;22(8):1467-72.

[113] De Sanctis V, Galimberti M, Lucarelli G, Polchi P, Ruggiero L, Vullo C. Gonadal function after allogenic bone marrow transplantation for thalassaemia. Arch Dis Child 1991;66(4):517-20.

[114] Gharwan H, Neary NM, Link M, Hsieh MM, Fitzhugh CD, Sherins RJ, et al. Successful fertility restoration after allogeneic hematopoietic stem cell transplantation. Endocr Pract 2014;20(9):e157-61.

[115] Rahal I, Galambrun C, Bertrand Y, Garnier N, Paillard C, Frange P, et al. Late effects after hematopoietic stem cell transplantation for beta-thalassemia major: the French national experience. Haematologica 2018;103(7):1143-9.

[116] Santarone S, Natale A, Olioso P, Onofrillo D, D'Incecco C, Parruti G, et al. Pregnancy outcome following hematopoietic cell transplantation for thalassemia major. Bone Marrow Transplant 2017;52(3):388-93.

[117] Bernaudin F, Dalle JH, Bories D, de Latour RP, Robin M, Bertrand Y, et al. Longterm event-free survival, chimerism and fertility outcomes in 234 patients with sickle-cell anemia younger than 30 years after myeloablative conditioning and matched-sibling transplantation in France. Haematologica 2020;105(1):91-101.

[118] Ciurea SO, Cao K, Fernandez-Vina M, Kongtim P, Malki MA, Fuchs E, et al Correction: The European Society for Blood and Marrow Transplantation (EBMT) Consensus Guidelines for the Detection and Treatment of Donor-specific Anti-HLA Antibodies (DSA) in Haploidentical Hematopoietic Cell Transplantation. Bone Marrow Transplant 2019;54(5):784

[119] Ciurea SO, Cao K, Fernandez-Vina M, Kongtim P, Malki MA, Fuchs E, et al. The European Society for Blood and Marrow Transplantation (EBMT) Consensus Guidelines for the Detection and Treatment of Donor-specific Anti-HLA Antibodies (DSA) in Haploidentical Hematopoietic Cell Transplantation. Bone Marrow Transplant 2018;53(5):521-34

[120] Abboud M, Laver J, Blau CA. Granulocytosis causing sickle-cell crisis. Lancet 1998;351(9107):959.

[121] Adler BK, Salzman DE, Carabasi MH, Vaughan WP, Reddy VV, Prchal JT. Fatal sickle cell crisis after granulocyte colony-stimulating factor administration. Blood 2001;97(10):3313-4

[122] Fitzhugh CD, Hsieh MM, Bolan CD, Saenz C, Tisdale JF. Granulocyte colony-stimulating factor (G-CSF) administration in individuals with sickle cell disease: time for a moratorium? Cytotherapy 2009;11(4):464-71.

[123] Kauf TL, Coates TD, Huazhi L, Mody-Patel N, Hartzema AG. The cost of health care for children and adults with sickle cell disease. Am J Hematol 2009;84(6):323-7.

[124] Weidlich D, Kefalas P, Guest JF. Healthcare costs and outcomes of managing beta-thalassemia major over 50 years in the United Kingdom. Transfusion 2016:56(5):1038-45.

[125] Ballas SK. The cost of health care for patients with sickle cell disease. Am J Hematol 2009;84(6):320-2.

[126] Majhail NS, Mau LW, Denzen EM, Arneson TJ. Costs of autologous and allogeneic hematopoietic cell transplantation in the United States: a study using a large national private claims database. Bone Marrow Transplant 2013;48(2):294-300.

[127] Coquerelle S, Ghardallou M, Rais S, Taupin P, Touzot F, Boquet L, et al. Innovative Curative Treatment of Beta Thalassemia: Cost-Efficacy Analysis of Gene Therapy Versus Allogenic Hematopoietic Stem-Cell Transplantation. Hum Gene Ther 2019;30(6):753-61.

[128] Arnold SD, Brazauskas R, He N, Li Y, Aplenc R, Jin Z, et al. Clinical risks and healthcare utilization of hematopoietic cell transplantation for sickle cell disease in the USA using merged databases. Haematologica 2017;102(11):1823-32.

[129] Saenz C, Tisdale JF. Assessing Costs, Benefits, and Risks in Chronic Disease: Taking the Long View. Biol Blood Marrow Transplant 2015:21(7):1149-50.

[130] Gratwohl A, Baldomero H, Aljurf M, Pasquini MC, Bouzas LF, Yoshimi A, et al. Hematopoietic stem cell transplantation: a global perspective. JAMA 2010;303 (16):1617-24.

[131] Leonard A, Tisdale JF. Stem cell transplantation in sickle cell disease: therapeutic potential and challenges faced. Expert Rev Hematol 2018;11(7):547-65.

[132] Jensen K. Bluebird proposes installment plan for LentiGlobin gene therapy2019. Available from: https:/www.biopharmadive.com/news/jpm19-bluebird-proposes-installment-plan-for-lentiglobin-gene-therapy/545646/. Accessed 1 June 2021.

[133] Hampson G, Towse A, Pearson SD, Dreitlein WB, Henshall C. Gene therapy: evidence, value and affordability in the US health care system. Journal of Comparative Effectiveness Research 2018;7(1):15-28.

[134] Hettle R, Corbett M, Hinde S, Hodgson R, Jones-Diette J, Woolacott N, et al. The assessment and appraisal of regenerative medicines and cell therapy products: an exploration of methods for review, economic evaluation and appraisal. Health Technol Assess 2017;21(7):1-204.

[135] Gregory Daniel NL, Jeff Marrazzo, Mark B. McClellan. Advancing Gene Therapies And Curative Health Care Through Value-Based Payment Reform2017. Available from: https://www.healthaffairs.org/do/10.1377/hblog20171027.83602/full/. Accessed 1 June 2021.

[136] Services CfMM. Medicaid Program; Establishing Minimum Standards in Medicaid State Drug Utilization Review (DUR) and Supporting Value-Based Purchasing (VBP) for Drugs Covered in Medicaid, Revising Medicaid Drug Rebate and Third Party Liability (TPL) Requirements. 2020. p. 37286-322. Accessed 1 June 2021. 